\title{
Chitin, Chitosan and Glucan, Properties and Applications
}

\author{
Manal G Mahmoud, Ebtsam M El Kady* and Mohsen S Asker \\ Microbial Biotechnology Department, National Research Centre, Egypt
}

*Corresponding author: EM El Kady, Microbial Biotechnology Department, National Research Centre, Giza, Egypt.

Received Date: June 17, 2019

Published Date: August 02, 2019

\begin{abstract}
This review characterizes the most common natural polysaccharides and the presence of huge structural tendencies for the production of biologically active compounds, which have innovative characteristics and functions of different applications, especially in the field of biomedicine. such as glucan, chitin and chitosan (very basic) of living organisms and their properties involves solubility in different media, viscosity, behavior polyelectrolyte, forming polyoxysalt, visual ability to form films, chelation's metals, and structural properties as molecular weight (Mw) and conformation. Their applications are also demonstrated, such as: biomedicine (antioxidant, anti-bacterial, anti-fungal anti-viral, hepatoprotective, cardiovascular, anti-hypercholesterolemia, anti-parasitic, anti-diabetic, detoxification, anti-tumor and immunomodulating), agriculture, food industry, textile industry, and paper making. Interestingly, the relationship between biological activity and chemical structure is elucidated for glucan, chitin, chitosan (molecules with various degree of acetylation DA) and Mw. In conclusion, many vital industrial and medical applications are offered, for chitin, chitosan and glucan, and they are known as vital and a novel biological compound, which have occupation priority of their compatibility (low immunogenicity and nontoxic) and biodegradation with non-toxic. Besides that, glucans, chitin, and chitosan have a lot of interest because of their positive effects on animal and human health, and they are natural polysaccharides found in different sources, such as plants, animals, insects and microorganisms.
\end{abstract}

\section{Introduction}

\section{Chitin}

Chitin may be inferred from the Greek saying 'chiton', importance and cover of mail and might have been uniquely, initially utilized within 1811 by Bradconnot [1,2]. Poly $\beta$-(1-4)$\mathrm{N}$-acetyl-D-glucosamine or chitin (Figure 1 ) is the second plentiful bio-polysaccharide of ace significance to nature following cellulose. This biopolymer is synthesized by massive number of living organisms [3,4]. In the native nation, chitin occurs as ordered crystalline micro fibrils which form structural ingredients in the exoskeleton of arthropods or in the cell walls of yeast and fungi. So far, the major traditional sources of chitin are shrimp and crab shells. In industrial processing, chitin is extracted by acid treatment to dissolve the calcium carbonate followed by alkaline solution to dissolve proteins. In addition, a decolorization step is often added in order to eliminate pigments and obtain a colorless pure chitin. All those processing must be compatible to chitin source, due to variations in the ultrastructure of the original material, to produce high quality of chitin, and chitosan (partial deacetylation). Chitin is niggardly and infusible soluble through transformation into various conformations. The solubility is a main problem in the enhancement of both treatment and use of chitin add to its characterization. Chitin has extra applications while converting to chitosan [5-7] (Figure 1).

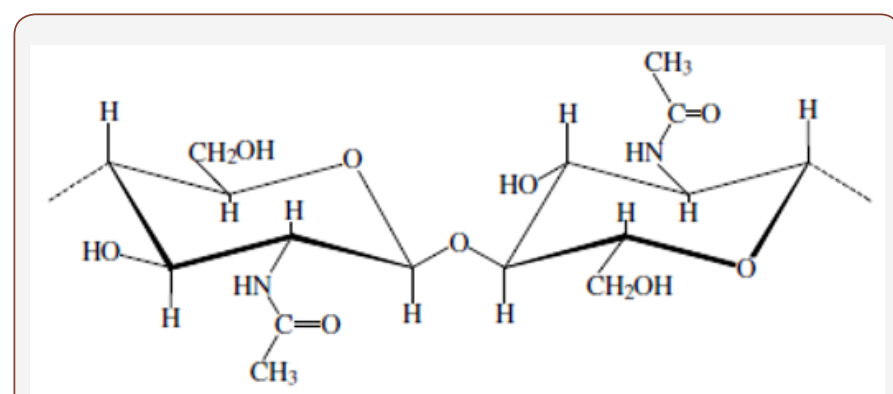

Figure 1: Structure of Chitin.

\section{Chitosan}

Chitosans are produced from the shells of crabs and shrimps, insects, and the bone plates of squids and microorganism. In fungal cell walls, chitosan exists in two forms, as free chitosan and covalently bounded to $\beta$-glucan. Minimum cost products of these two polymers could be produced utilizing industrial waste mycelia 
and mycelia gained from cultivation of fungus in medium gained from industrial by-products. The quality and quantity of chitosan extracted from fungal mycelia depends on fungal strain, type of fermentation, medium composition such as trace metal content and concentration of nutrients, $\mathrm{pH}$, incubating time, and chitosan extraction procedure [8]. Chitosan is the deacetylated derivative of chitin [5-7], which is chemically defined as a copolymer (Figure 2) of $\alpha-(1 \rightarrow 4)$ glucosamine $\left(\mathrm{C}_{6} \mathrm{H}_{11} \mathrm{O}_{4} \mathrm{~N}\right) \mathrm{n}$, having various number of $\mathrm{N}$-acetyl groups [9]. It is white to light red solid powder, soluble in organic acids but insoluble in water. The degree of acetylation of chitosan is recognized by a percentage of DA or as the molar fraction of $\mathrm{N}$-acetylated units (DA) in regards provisions of chitin also chitosan, distinctive samples connected to drug release, wound dressing, or would portray, and biofilms. It may be critical will recall that chitin will be a regular polymer and in addition biodegradable and biocompatible in the body, consequently generally connected for pharmaceutical and biomedical provisions. Additionally, perfect film figuration properties are valuable for artificial skin, packaging and wound dressing. Nanoparticles are becoming increasingly significant in numerous areas, inclusive catalysis, information storage, and biological applications. Their unique size-dependent properties make these materials eminent; chitin and chitosan are the second maximum available biopolymer after cellulose. Chitosan extraction consists of four general steps such as demineralization, deproteinization, decolorization and $\mathrm{N}$-deacetylation $[4,8]$ (Figure 2) (Table 1).

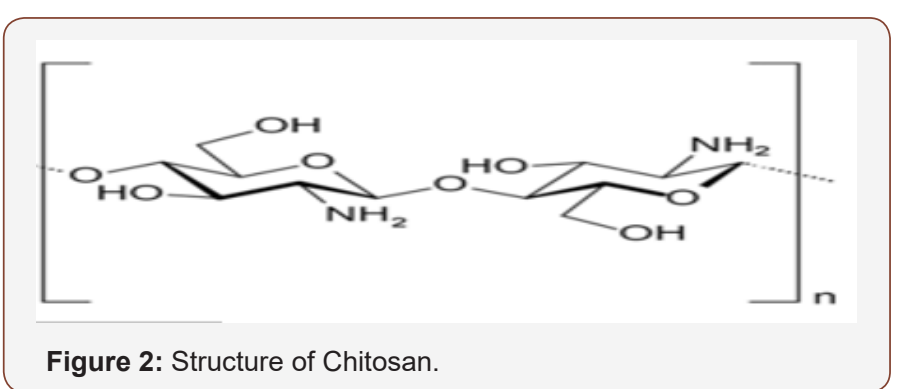

Table 1: Sources of Chitin and Chitosan.

\begin{tabular}{|c|c|c|}
\hline Sea Animals & Insects & Micro-Organisms \\
\hline Crustaceans & Scorpions & Green algae \\
\hline Coelenterate & Brachiopods & Yeast( $\beta$-Type) \\
\hline Annelida & Cockroaches & Fungi (cell walls) \\
\hline Mollusca & Spiders & Mycelia penicillium \\
\hline Lobster & Beetles & Brown algae \\
\hline Shrimp & Ants & Chytridiaceae \\
\hline Prawn & & Ascomydes \\
\hline Krill & & Blastocladiaceae \\
\hline Crab & & Spores \\
\hline
\end{tabular}

\section{Chitin and Chitosan Processing}

Chitin and chitosan are natural resources expectation for a market. They were waste products of shrimp and the crabbing canning industry. Materials of chitin produced as processing waste from fungi, shellfish, clams, krill, oysters, and squid. Traditionally chitin and chitosan are of massive importance due to their relatively great percentage of nitrogen (6.89\%) compared to synthetically substituted cellulose. The crustacean shells mainly include the removal of proteins and the dissolution of calcium carbonate that is present in crab shells in high concentrations. The resulting chitin is deacetylated in $40 \%$ sodium hydroxide at $120{ }^{\circ} \mathrm{C}$ for $1-3 \mathrm{~h}$. This treatment produces $70 \%$ deacetylated chitosan. The following four general steps (Figure 3) in chronological demand of the process are needed to produce chitosan from crustacean shells:

- Deproteinization.

- Demineralization (better property than the existing process).

- Decolouration.

- Deacetylation.

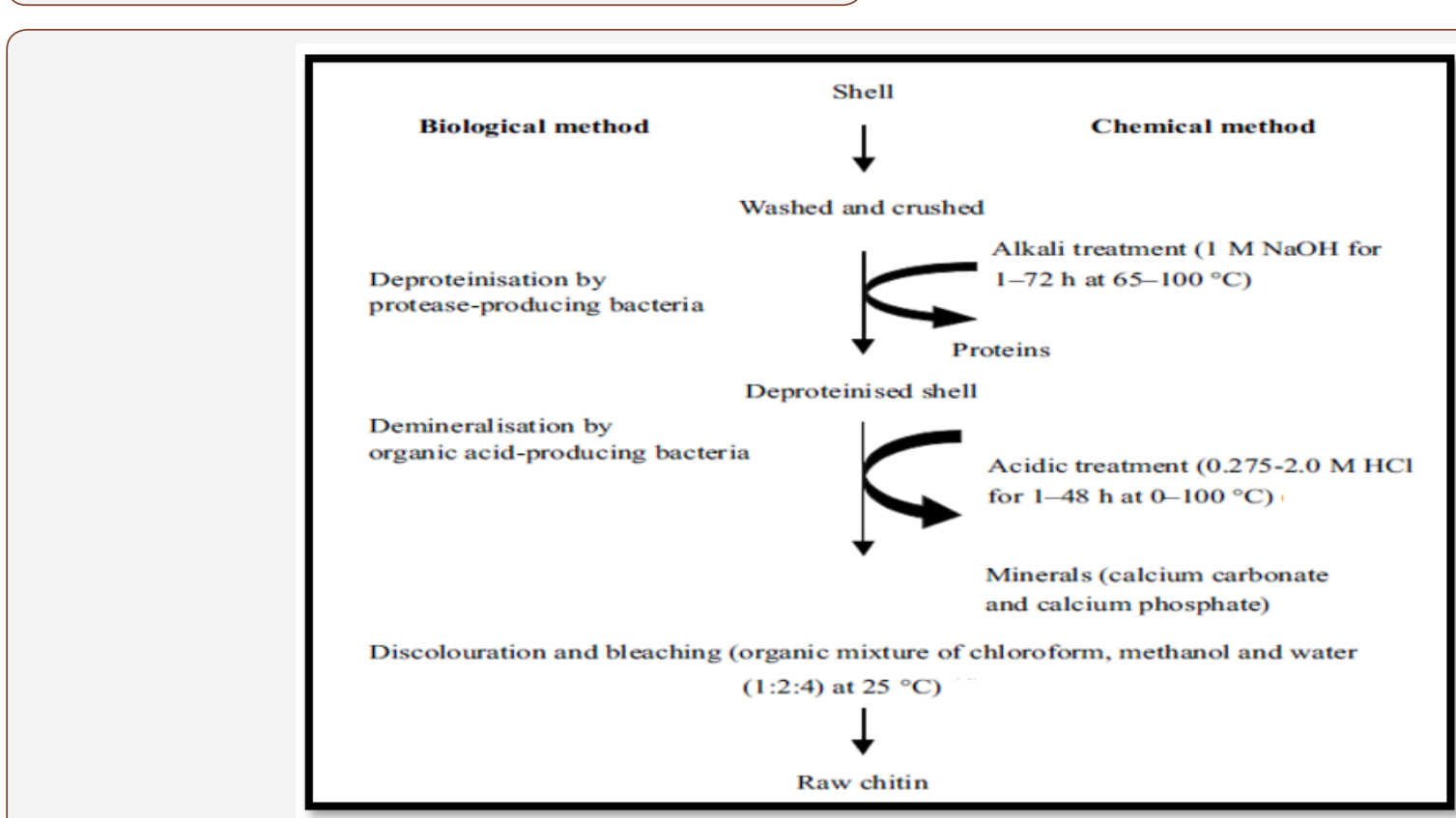

Figure 3: Chitin and Chitosan Processing by Chemical and Biological Methods. 


\section{Chitin Characterization}

\section{Chitin morphology}

Contingent upon its source, chitin exists likewise two allomorphs, in particular the $\alpha$ - also $\beta$-forms $[10,11]$, which could make recognized by means of strong-state NMR spectroscopies , furthermore infrared mutually with X-beam diffraction in the robust state, chitin chains are collected by means of those H-bonds net which dominances the solvency, swelling, furthermore reactivity. $\alpha$-Chitin isomorph is beyond question those primary abundant; it happens previously, yeast and fungal cell walls, crab tendons, lobster, to krill, and in shrimp shells, as for creepy crawly fingernail skin and of the local chitin, $\alpha$-chitin will be efficiently shaped via: re-crystallization from chitin $[12,13]$ result toward invitro biosynthesis [14,15] or enzymatic polymerization [16] with owing on helter skelter thermodynamical consistency for this isomorph. The rarer $\beta$-chitin may be discovered done consolidation for proteins done squid pens $[17,18]$ and in the tubes synthesized through vestimetiferan worms and pogonophoran $[19,20]$. Those crystallographic parameters of the two isomorphs tolerance us on find that there would two anti-parallel atoms for every unit cell done $\alpha$-chitin yet special case in $\beta$-chitin for a parallel request. Previously, these two structures, the chains need aid marshaled previously, sheets also found by means of intra-sheet hydrogen bonds. In addition to, $\alpha$-chitin, inter-sheet hydrogen securities forbid dispersion for little particles under the crystalline. No intersheet hydrogen securities, which penetrate the precious stone grid without troublous the sheet association and the crystallinity of the test. The evacuation of the occupant atom permits us on exchange of the premier state from claiming anhydrous $\beta$-chitin. The reactivity from claiming $\beta$-chitin isomorphs will be more stupendous over the $\beta$-isomorph, which may be noteworthy for compound, furthermore enzymatic transformations of chitin [19] with deduce, both $\alpha$ and $\beta$. Manifestations need aid insoluble altogether those broad solvents this insolubility may be an fundamental issue in the perceivability of the improvement from claiming transforming and requisitions of chitin.

\section{Molecular weight (Mw)}

Chitosan molecular weight assignments have been ascertained through HPLC, those weight-average (Mw) from claiming chitosan also chitin need been acquired by means of light scattering, viscometry is uncomplicated course also a quick for those determination of the molecular weight those accused nature about chitosan clinched alongside corrosive solvents and chitosan affinity on settle on amassed complexes need additional consideration at these constants need aid connected. Additionally, converting chitin under chitosan diminishes the molecular weight, transforms those reach of deacetylation, and toward method for that the charge circulation changes, which need huge impacts on the agglomerated. Park, et al. [20] Elucidated that low Mw chitosans need aid additional dynamic over the individuals with more excellent Mw chitosan tests with negligible Mw (1-3 kDa) seemed higher possibility should search different radicals. Different examination exhibited that low-
Mw chitosans could presentation more than $80 \%$ about superoxide radical searching action during $0.5 \mathrm{mg} / \mathrm{mL}$ concentrations [21]. The impact of chitosan Mw (30, 90, and $120 \mathrm{kDa}$ ) on the cell reinforcement movement to salmon skin might have been as well mulled over [22]. The effects from claiming this examine shown that constantly on chitosans indicate cell reinforcement activities, which diminishing salmon lipid oxidation, those $30 \mathrm{kDa}$ chitosan example hosting those higher cell reinforcement movement to addition, greatly deacetylated $(90 \%)$ chitin need aid a greater amount alluring to searching hydroxyl, superoxide, DPPH, furthermore carbon centered radicals [23]. Despite the fact that those exact component from claiming radical searching action may be not evident, it is imputed on amino, furthermore hydroxyl bunches (attached should $\mathrm{C}_{2}, \mathrm{C}_{3}$ Also $\mathrm{C}_{6}$ positions of the pyranose ring) reacting with flimsy allowed radicals, which facilitate structuring for stable macromolecule radicals.

\section{Solubility of chitin}

In the robust state, the chains would anti-parallel clinched alongside $\alpha$-chitin and parallel previously, $\beta$-chitin [24]. Their crystalline structures were reviewed in distinctive papers utilizing X-beam diffraction technique, [25] IR spectroscopy, [26] also strong state 13C-NMR [27] is an for the most part connected strategy for separation of the two isomorphs [28] to determination of the deacetylation degree for chitin (AD) and control for purification states.

\section{Viscosity}

Unluckily, physical properties for chitin in result can't a chance to be anatomized effectively owing to poor information. Disintegration is needed with assess the molecular weight as well as to treats chitin (chitin can't make transformed over liquid state). Vicinity of aggregates in result disallows light scattering estimations and overestimates the molecule weights. Therefore, the sweeping statement appropriate strategy here may be viscometry the place the Mark-Houwink parameters need aid perceived under characterized thermodynamic states connected (solvent, temperature). A standout amongst the mostaccioli distinguished framework will be rely on upon complex framing the middle of chitin, furthermore LiCl clinched alongside dimethyl acetamide (DMAC) dissolvable (5\%). Test qualities for parameters $\mathrm{K}$ and a relating legitimate viscosity [ $\eta$ ] also molecular weight $(M)$ for chitin in this dissolvable would determinate from well-known MarkHouwink comparison agreeing to: -

$$
\eta(\mathrm{ml} / \mathrm{g})=\mathrm{K} \times \mathrm{M} \times \mathrm{A}
$$

With $\mathrm{K}=7.6 \times 10^{-3}, \mathrm{~A}=0.95$ at $30^{\circ} \mathrm{C}[29] ; \mathrm{K}=2.4 \times 10^{-1}$ and $\mathrm{A}=$ 0.69 at $25^{\circ} \mathrm{C}[30]$.

A review for chitin and chitosan directing, including those address of their dissolvability might have been recently distributed clinched alongside join to fiber transforming [31]. It need been elucidated that chitin will be fit with make transformed from results. Additionally, chitin, concerning illustration different 
polysaccharides deduced starting with cellulose, need flawless filmforming properties, furthermore immaculate strength affirmed by those strongholds of a hydrogen security system the middle of developed chains. Chitin provides for fundamental properties should. Those novel materials owing on its, biocompatibility, biodegradability and non-toxicity, for antimicrobial action and little immunogenicity.

\section{Degree of acetylation}

Rinaudo and Domard [32] stated that that dissolvability of chitosan might make depicted not just toward those portions of 2-acetamido-2-deoxy-glucose units in the molecule as well as by the $\mathrm{N}$-acetyl aggregation circulation Aiba [33]. Exhibited that deacetylation response executed under heterogeneous states was provides for a different dissemination of $\mathrm{N}$-acetyl-glucosamine and glucosamine residues for a few blocks' wise acetyl bunch division along polymeric chains. Thus, level about amassed and dissolvability from claiming chitosan could transform over watery results prompting varieties to their normal qualities. To instance, physicochemical properties about such chitosans might fluctuate starting with the individuals from claiming haphazardly acetylated chitosans picked up under homogeneous states. Furthermore, progressions done chitosan preparation might additionally bring about varieties about DA, appropriation about acetyl bunches along that viscosity in result and Mw chains [34,35].

\section{Properties of chitosan}

\section{Chemical properties of chitosan [36].}

The chemical properties of chitosan include:

- Linear amino polysaccharide with too highly nitrogen content.

- Rigid glucosamine structure; rise hydrophilicity, crystallinity.

- Weak base; deprotonated amino group acts a powerful nucleophile (pKa 6.3).

- Enable to form hydrogen bonds intermolecularly; raise viscosity.

- Consisting of big reactive groups for chemical activation and cross-linking.

- Insoluble in organic solvents and water; soluble in dilute hydrous acidic solutions.

- Forms salts with inorganic acids and organic.

- Chelating and complexing properties.

- Ionic conductivity.

- $\quad$ Polyelectrolytes (at acidic pH).

- Cationic biopolymer with rise charge density (one positive charge per glucosamine residue).

- Flocculating agent; interacts with negatively charged molecules.

- Entrapment and adsorption properties; separation and filtration.

- Film-forming ability; adhesivity materials to isolation of biomolecules.

\section{Chitosan based materials}

Results about chitosan ready over acidic medium need aid approached of the necessary conformity (spun for fibers, casted to a film, solidify dried or sponges, and so on, drenched for a basic result, washed furthermore dried. The medication for chitosan may be less demanding over that about chitin yet the consistency of the materials will be bringing down because of the more amazing hydrophilic character and especially that $\mathrm{pH}$ defenselessness. For moreterrificstability, chitosan mighta chance to be crosslinked using reagents such as, epichlorohydrin, 1,4-butanediol di-glycidyl ether, glutaraldehyde or di-isocyanate [37]. Substantially chitosan hydro gels were obtained by medication for multivalent anions as citric $[38,39]$ alternately oxalic $[40,41]$ corrosive or tri-polyphosphate [42] composites also blends are sporadically prepared taking necessity of the poly cationic 2-properties about chitosan in acidic states. Previously, fact, chitosan vicinity a polyelectrolyte may be fit to structure intriguing hydro gels (electrostatic complexes) for oppositely accused macromolecules. Electrostatic polyelectrolyte complexes (EPC) are shown in the written works including chitosan complexes with engineered or characteristic polymers [3]. Electrostatic associations between chitosan also lipidic vesicles need aid additionally huge in the pharmaceutical and living fields owing will permeabilizer parts and bio adhesive of chitosan. Covering of liposomes with chitosan also rises stabilizes the composite membrane, furthermore biocompatibility versus $\mathrm{pH}$ and in addition ionic centralization [43]. Recently, these electrostatic co-operations would utilize to preparation for layer-by-layer polyelectrolyte movies alternately capsules rely on upon accused biocompatible polysaccharides or chitosan manufactured polyelectrolyte [4446]. Core-shell phospholipids nanoparticles were settled toward layer-by-layer self-assembly from claiming anionic alginate and cationic chitosan, furthermore, were recommended for protein free [45] alginate, furthermore chitosan electrostatic complexes bring been particularly connected in this way to living provisions [46-48]. Complexes framed between RNA alternately DNA also chitosan would truly under further satisfaction clinched alongside significantly laboratories, DA and the charge thickness of chitosan are basic for the intricate dependability [49-53].

\section{Biological properties of chitosan}

Besides the diverse chemical properties, chitosan shows various biological properties which are summarized as follows [54,55]:

- Biocompatible (Safe, Biodegradable to normal body constituent's natural polymer, and non-toxic)

- Binds to mammalian and microbial cells aggressively

- Renovated effect on connective gum tissue 
- Hemostatic (causes stop bleeding)

- Accelerates the formation of osteoblast responsible for bone formation

- $\quad$ Fungistatic (stopping the growth of fungi)

- $\quad$ Spermicidal (birth control)

- Anti-cholesteremic (cholesterol reducing agent)

- Anticancer or Antitumor (inhibiting the growth of tumor or cells)

- Central nervous system depressant (reducing the brain activity)

- Immunoadjuvant (included in the improvement of immune response)

\section{Relation between Chemical Structure and Biological} Activities

\section{Chitin and chitosan}

In place to chitosan and derivatives possess have precise beneficially properties for example, biodegradability, biocompatibility, safety also intriguing living activities, that's only the tip of the iceberg consideration need been drive will their provisions especially Previously, biomedical, biotechnology, sustenance and pharmaceutical fields [56,57]. Around their amiable living activities anti-microbial, anti-tumor, and cell reinforcement exercises, will make examined clinched alongside point of interest beneath. These properties need aid extraordinarily prestigious in the field for nourishment bundling, furthermore protection will stay away from the utilization of concoction additives and to process eatable antimicrobial movies owing of the flawless film framing properties for chitosan. Chitosan similarly as a polymeric constituent for a great cell reinforcement also antimicrobial properties, doesn't move effectively out of the ensuring novel into a film and need more terrific obstruction properties. This might have been formerly elucidated clinched alongside a number of studies [58-60]. Friedman and Juneja [59] for example, the individuals for examined those antimicrobial activities of chitosan previously, solution, eatable movies, powders and covering against nourishment borne pathogens, pathogenic, Infections, spoilage bacteria, and growths for different sustenance classifications. These incorporate apples and oranges juices, dairy, eggs, meat, cereal, and fish results. They propose that little-molecular-weight chitosans at pH beneath 6 demonstrates ideal states for accomplishing affable anti-oxidative and antimicrobial preservative impacts previously, fluid also strong nourishments [60]. The utilization from claiming chitosan also derivatives in the nourishment industry might have been, additionally depicted in the survey about. They elucidated that these biopolymers indicate an extensive variety about unrivaled requisitions directing, including protection about nourishments from microbial retro gradation and shaping from claiming biodegradable films. Alishahi and Aider [58], stated that chitosan movies done bundling requisition have a tendency on offer imperviousness should fat promulgation and specific gas permanganic corrosive. But inconvenience hails starting with their little safety with water and water vapor transmission [61]. This air may be because of those mightily hydrophilic characters in a far-reaching way of chitosan, a property that prompts climb communication for water atoms. For this reason, polymer blending or the use about bio-composites also multilayer frameworks need aid possibility methodologies will get ready chitosan-based bioactive coatings.

\section{Application of Chitin/Chitosan}

Innovative work in the field about chitin/chitosan furthermore its requisition raised dramatically to cutting edge a long time. This spurs up those improvements about novel results also requisition from claiming chitin/chitosan in distinctive fields. Chitin/Chitosan need been effectively connected and used in nourishment and feed, pharmaceutical and medicine, materials, furthermore textiles, agriculture, also in the new rising field of nanotechnology.

\section{Agriculture}

Previously, Thailand chitin/chitosan need been used concerning illustration foliage shower with prompt expand nature and handling what's more expand ailment. Safety from claiming orchid, furthermore other enlivening plants, it might have been analyzed and connected to products for example, palm, corn, rice, cassava, also a number of tropical fruits with triumph. Chitin/Chitosan need been embedded under creature encourage to shrimps and fish Similarly as bolster covering and in addition supplemented in the drinking water for chickens, cattle, and porcine. However, the mechanism and entryway chitin/chitosan meet expectations over these provisions remains dark. Exact, furthermore broad examine must be performed with make that suitableness utilization of chitin/chitosan and its joined result. The utilization from claiming chitin/chitosan cam wood extricate best possible. Reaction when the suitableness molecular weight, percent level of deacetylation, chain length, and system need aid connected.

\section{Chitin/chitosan and textile}

Chitin/chitosan might additionally make connected, furthermore utilization done various other provisions for example, material owing with its. Antimicrobial property, chitin/chitosan when transformed into wet turn under fibers or novel into a film could be incorporated under both woven, furthermore non-woven fabric and cam wood control those smell and forbid microbial development.

\section{Chitin/chitosan in food and nutraceutical products}

Sustenance also nutraceutical need been a standout amongst those expert provisions from claiming chitin/chitosan, since it may be the expert hotspot of amino sugar, D-glucosamine also N-acetylglucosamine. Chitosan could likewise as a thickening agent, also advanced investigations need. Exhibited that chitosan could respond with proteins with fluctuate those interactional about protein brought about upgrade from claiming. Composition of the product, 
and additionally water maintenance for sustenance items when chitosan will be included under a few nourishments. Item it might likewise go about as restrain microbial development, furthermore an nourishment preservative chitin and its derivatives would know to bring vast reach for biological activities directing, including antimicrobial impacts, antioxidant effects, and significantly other properties that might be used in the sustenance industry should improve food quality, shelf-life, and safety [22]. Yearly, in 80000 tons for chitin would transform from streamlined wastes, especially starting with those fish preparing industry (Table 2).

Table 2: Some Application of Chitin and Chitosan.

\begin{tabular}{|c|c|}
\hline Application & Example \\
\hline \multicolumn{2}{|r|}{ Chitin } \\
\hline Biomedical and Pharmaceutical Materials & Sponges and bandages for the treatment of wounds and suture threats. \\
\hline Agriculture & Defensive inducing mechanism in plants. \\
\hline Water Engineering & For decontaminated plutonium-containing wastewater and water-containing methylmercury acetate. \\
\hline \multicolumn{2}{|r|}{ Chitosan } \\
\hline Biomedical and Pharmaceutical Materials & $\begin{array}{l}\text { Treating major burns, preparation of artificial skin, surgical sutures, contact lenses, blood dialysis } \\
\text { membranes and artificial blood vessels, as antitumor, blood anticoagulant, ant gastritis, hemostatic, } \\
\text { hypocholesterolemia and antithrombogenic agents, in drug and gene-delivery systems, and in dental } \\
\text { therapy. }\end{array}$ \\
\hline Cosmetics & Skin- and hair care products. \\
\hline \multicolumn{2}{|r|}{ Cell growth and proliferation in tracheal cartilage, nerve } \\
\hline Tissue Engineering & $\begin{array}{l}\text { Bone tissue repair and regeneration materials for cartilage repair Porous 3D scaffolds of chitosan- } \\
\text { calcium phosphate composites for bone regeneration Chitosan-chondroitin sulphate sponges in bone } \\
\text { regeneration Chitosan-calcium alginate capsules with the aim of developing an artificial pancreas for the } \\
\text { treatment of diabetes mellitus. }\end{array}$ \\
\hline Agriculture & Seed- and Food-coating fertilizer and fungicide. \\
\hline Chromatographic Media and Analytical & $\begin{array}{c}\text { Immobilization of enzymes, as a matrix in affinity and gel permeation chromatography and as enzymes } \\
\text { subtracts. }\end{array}$ \\
\hline Food and feed Additives & $\begin{array}{l}\text { Classification and de-acidification of fruits and beverages, color stabilization, reduction of lipid } \\
\text { adsorption, natural flavor extender, controlling agent, food preservative and antioxidant, emulsifying, } \\
\text { thickening and stabilizing agent, livestock and fish-feed additive, and preparation of dietary fibers. }\end{array}$ \\
\hline Water Engineering & $\begin{array}{l}\text { Wastewater treatment, recovery of metal ions and pesticides, removal of phenol, proteins, radioisotopes, } \\
\text { PCBs and dyes, recovery of solid materials from food processing, wastes, removal of petroleum and } \\
\text { petroleum products from wastewater, as an adsorbent for removal of color from dyehouse effluents, } \\
\text { metal capture from wastewater, color removal from textile mill effluents. }\end{array}$ \\
\hline \multicolumn{2}{|r|}{ Chitin and Chitosan } \\
\hline Medicine and Pharmacy & $\begin{array}{l}\text { Wounds, ulcers and burns treatment, due to its hemostatic properties and its accelerating wound healing } \\
\text { effect. }\end{array}$ \\
\hline \multirow{3}{*}{ Agriculture } & Controlling parasitic nematodes in soils \\
\hline & $\begin{array}{l}\text { The antimicrobial properties of chitosan and its excellent film forming aptitude have been exploited in } \\
\text { the post-harvest preservation of fruits and vegetables in soil, enhance plant-microorganism symbiotic } \\
\text { interactions to the benefit of plants, as in the case of mycorrhizas chitosan and its derivatives. }\end{array}$ \\
\hline & Induce favorable changes in the metabolism of plants and fruits. \\
\hline
\end{tabular}

\section{Antioxidant activity}

Reactive oxygen species (ROS) for example, such that hydroxyl radicals, $\mathrm{H}_{2} \mathrm{O}_{2}$, also superoxide's, also drive should oxidative stress which will be associated for separate pathologies: cardiovascular disease [62], premature aging, arthritis [63], rheumatoid, inflammation [64] and cancer [65]. Chitin is around diverse mixes (vitamin E and C) that need shown antioxidant impacts [66]. Consequently, it might a chance to be included likewise an element to the handling for practical nourishment which weight square dietrelated also age-related maladies [67]. The oxidation from claiming substantially unsaturated sustenance lipids makes off- rancidity also favors. Ordinarily, synthetic antioxidants for example, such that butylated hydroxy anisole (BHA) and butylated hydroxytoluene (BHT) would utilize [55]. However, due to possibility wellbeing dangers connected with such compounds, additional characteristic and safe antioxidants need turned preferred [68]; especially if a shortage about poisonous quality might make elucidated. So were as from claiming $1 \%$ chitosan came about to a diminish of $70 \%$ in 2-thiobarbituric corrosive sensitive substances (TBARS) values from claiming meat following $72 \mathrm{~h}$. of stockpiling in $4{ }^{\circ} \mathrm{C}$. Chitosan's severe appears to a chance to be identified with its chelation of the spare iron that is freed starting with the heme proteins for meat through high temperature preparing likewise meats, lipid oxidation for unsaturated un-saturated fat acids exists previously, fish [69]. This oxidation will be catalyzed by the climb focuses about prooxidants such concerning illustration metal ions also hemoglobin in the fish muscle [3]. Those antioxidant impacts of chitosan varies with its viscosity, molecular weight, furthermore fixation as 
shown Eventually Tom's perusing. Chitosans picked up from crab shell wastes were inspected with respect to herring tissue (Clupea harengus). Chitosan with different viscosity were utilized (360, 57 and $14 \mathrm{cP}$ ) will treat the fish tests. The relating viscosity normal molecular weights were $1.8 \times 10^{6} ; 9.6 \times 10^{5}$ also $6.6 \times 10^{5} \mathrm{Da}$. at three biopolymers advertised antioxidant effects, as, they brought down TBARS, peroxidase values, also aggregate unstable aldehydes. However, those most noteworthy action might have been spotted for those low viscosity chitosan $(14 \mathrm{cP})$. These effects were compared for the individuals picked up for commercial antioxidants (BHT, BHA, also tertiary butyl hydroquinone (TBHQ)) also it seemed that those 14-cP example might have been all the more. Chitosans might hinder lipid oxidation by means of chelating ferrous ions existing in the fish model system [68], therefore evacuating pro-oxidant movement from claiming ferrous ions alternately denying their transformation with ferric particle additionally spotted comparable effects for chitosan with different molecular weights (30, 90 and $120 \mathrm{kDa}$ ) Previously, Atlantic salmon (Salmo salar) [3,22]. The antioxidant movement might have been assessed as decreased TBARS and brought up DPPH spare radical-scavenging movement those searching impact about chitosan might have been contrasted with that for BHT and a proportional effectiveness from claiming 85\% might have been picked up. Moreover, those least molecular weight chitosan (30 kDa) had shown those most elevated action.

\section{Preservatives of food}

Chitin also its derivatives could make used in the nourishment industry likewise nourishment additives [70,71] They need an anti-microbial action which permits them will save foodstuff from microbial retro gradation. The antibacterial activity of chitinous materials need been connected will their positive charges which respond for the negative charges of bacterial cell walls, prompting drainage of the intracellular particles of the microorganisms [72]. As were as from claiming chitosan should nourishment keeps microorganisms' development and deflect poor appearance, off flavors, furthermore financial harms watched that through including chitosan will cheddar it enhanced its mycological nature [73]. Yeast also mold development were halted, furthermore shelflife might have been protracted.

\section{Antimicrobial properties and packaging}

The antibacterial properties for chitosan need additionally been connected similarly as animated eatable bundling [74]. Biofilms bring been shaped starting with chitosan that tolerance long expression capacity of sustenance Items antimicrobial coating about fruits, grains, vegetables, and fish delay microbial infestation concerning illustration chitosan demonstrations as a protective obstruction to enhance those dietary calibers and tactile of the nourishment [75,76]. Furthermore, continuously a protective barrier, eatable biopolymer movies might make connected concerning illustration transporters from claiming bioactive mixes with enhancing nourishment caliber. Polymeric bioactive films might be united with different antimicrobial operators for example, such that bacteriocins, natural acids, proteins, plant extracts, antibiotics, fungicides, furthermore chelating operators (EDTA) on diminishing nourishment waste by means of pathogenic microorganisms and enhance shelf-life [77]. Chitosan-based eatable films would biodegradable and could make used alongside the result in the products packing. Moreover, they type bioactive films for flawless mechanical properties that constitute a shell keeping those calibers and the presence of the nourishment inside [78].

\section{Dietary fiber}

Chitosan have been connected similarly as a sourball about dietary fiber [79]. They need aid acknowledged on make practical sustenance's on account of about their non-digestibility through intestinal enzymes, which tolerance their similarly as prebiotics. They actuate valuable microscopic organisms in the gastrointestinal tract Bifidobacterium and Lactobacillus sp [80,81]. They could also go about as stabilizing, furthermore thickener operators [4,9].

\section{Pharmaceuticals}

To those conveyance for pharmaceutical parts chitin, chitosan, and their derivatives bring been applied. Because of their biodegradability, biocompatibility, and low poisonous quality they are a great part important polymer which might embody pharmaceutical actives, stay with them against degradation and furthermore permit their discharge over a prolonged period [82]. Different polymeric transporter systems for example, matrices, hydro gels, microsphere, nanoparticles, capsules, alternately micelles have been scrutinized [83]. The discharge of the active agents for the most part happens by means of development through those polymers, toward disorganization, alternately by degradation of the polymer disruption of the supra molecular structure of the conveyance systems [84]. Those conveyance drugs and gene need been perceived over as far back as a considerable length of time. Chitosan may be a standout amongst those mossy cups sweeping statement mulled over polymers around non-viral vectors for gene conveyance [25]. It will be acknowledged concerning illustration a great chosen one for gene transfection owing should electrostatic connection the middle of negatively accused DNA and cationic chitosan [85]. Numerous nucleic corrosive conveyance vehicles for gene help have been concentrated on for instance, viral vectors need been broadly connected to exemplification about genes. However, these transporters need a few side impacts (immunogenic, oncogenic, and furthermore cytotoxic) [86]. Furthermore, covering for pharmaceuticals with chitosan also its derivatives need aid connected on furnish regulated free for huge numbers drugs (anti-cancer, anti-inflammatory, anti-diabetic, antibiotic, also gastro-intestinal agents) [85]. The dynamic parts would additional powerful with a lessen side impacts also gradual liberated about animated constituents [66].

\section{Biomedical}

Chitin/chitosan will be those primary wellsprings for amino sugar, $\mathrm{N}$-acetyl-D-glucosamine and D-glucosamine discovered to nature. United states FDA need affirmed just the hydrolysis item from claiming chitin/chitosan will make the hotspot from claiming D-glucosamine, furthermore $\mathrm{N}$-acetyl-glucosamine for 
human utilization. These basic amino sugars need been use for the medicine of osteoarthritis previously, mankind's similarly as great concerning illustration joints for animals. Chitin/chitosan is, no doubt contemplated and utilized to drugs formulations concerning illustration intend of control liberate. It is utilized Likewise an adjuvant to immunizations for prosperity. Chitosan covered wound dressing might have been also searched since chitosan need antimicrobial movement and might quicken those recuperating procedure (Table 3). Bio-matrix to tissue building using chitosan and composite for different inactive material with chitosan might have been also constructed, furthermore need been advertised should need great potentials for further advancement and would connected over various sorts about biomedical provisions such concerning illustration tissue building, done lenses creation to ophthalmology, and wound recuperating [86-91]. Biopolymers need been connected to create living substitutes for deteriorated tissues, and to repair, look after, furthermore upgrade biofunctions [82]. Chitin and its derivatives have been connected as scaffolds, furthermore membranes (three dimensional porous structures) for tissue revival (nerves, bones, cartilage, kidneys, furthermore livers) [92-95]. Wound recuperating cam wood a chance to be postponed due to the antibacterial reliance of microorganisms concerning illustration an outcome about the infection, wounds are unable on mend appropriately, furthermore, take off disfiguring scares [96]. A chitin-based dressing need been advertised with protect wounds and blazes from bacterial spoiling [97]. Chitin and its derivatives go about as simulated skin matrixes that are skilled should push a fast dermal redesign after constantly utilized for blaze treatments, chitosan may be wanton toward endogenous enzymes this may be an fundamental preference as evacuating those wound dressing cam wood foundation trauma of the wounds and harm [36]. Chitin and its derivatives would a perfect gas dressing Likewise they dampen the wound interface, are penetrability will oxygen, furthermore, permit vaporous exchange, go about as a boundary with microorganisms, and are fit about eliminating abundance secretions [98]. Chitin and its derivatives have interesting properties for example, such that transparency, immunological compatibility, mechanical stability, optical clarity, gas permeability, wet ability, and adaptability that could make misused to contact lenses creation [99]. Chitosan need substituted engineered polymers for ophthalmological provisions Likewise it ensures solace also security through use [36]. Besides, owing will their wound recuperating qualities, furthermore antimicrobial, chitosan-based lenses need aid advantageous for harmed eyes [100].

Table 3: Chitin Derivatives and their Proposed uses.

\begin{tabular}{|c|c|c|}
\hline Derivative & Examples & Potential Uses \\
\hline N-Acyl Chitosans & $\begin{array}{l}\text { Formyl, acetyl, propionyl, butyryl, hexanoyl, octenyl, decanoyl, dodecanoyl, } \\
\text { tetradecanoyl, lauryl, myristoyl, palmitoyl, stearoyl, benzoyl, monochloroacitoyl, } \\
\text { dichloroacetyle, trifluoroacetyle, carbamoyl, succinyl, acetoxy benzoyl }\end{array}$ & $\begin{array}{l}\text { Textiles, membranes and } \\
\text { medical aids }\end{array}$ \\
\hline N-Carboxyalkyl (aryl) chitosans & $\begin{array}{l}\text { N-Carboxybenzyl, glycine-glucan (N-Carbomethyl chitosan), alanine glucan, } \\
\text { phenylalanine glucan, tyrosine glucan, serine glucan, glutamic acid glucan, } \\
\text { methionine glucan, leucine glucan }\end{array}$ & $\begin{array}{l}\text { Chromatographic media and } \\
\text { metal ion collection }\end{array}$ \\
\hline N-Carboxyacyl chitosans & $\begin{array}{l}\text { From anhydrides such as maleic, itaconic, acetyl thiosuccinic, glutaric, } \\
\text { cyclohexane, 1,2-dicarboxykic, phthalic, cis-tetrahy drophthalic, 5-norbomene-2, } \\
\text { 3-dicarboxylic, diphenic, salicylic, tremolitic, pyromellitic anhydride }\end{array}$ & $?$ \\
\hline 0-Carboxyalkyl chitosans & 0-Carboxymethyl, crosslinked 0-Carboxymrthyl & $\begin{array}{l}\text { Molecular sieves, viscosity } \\
\text { builders, and metal ion } \\
\text { collection }\end{array}$ \\
\hline Sugar Derivatives & $\begin{array}{l}\text { 1-Deoxygalactic-1-yl-, 1-deoxiglucit-1-yl-, 1-deoxymelibiit-1-yl-, 1-deoxylactit- } \\
\text { 1-yl-, 1-deoxylactit-1-yl-4(2,2,6,6-tetramethylpiperidine-1-oxyl)-, 1-deoxy-6'- } \\
\text { aldehydolactit-1-yl-, 1-deoxy-6'-aldehydomelibiit-1-yl-, cellobiit-1-yl-chitosans, } \\
\text { products obtained from ascorbic acid }\end{array}$ & $?$ \\
\hline Metal ion Chelates & Palladium, Copper, Silver, Iodine & $\begin{array}{l}\text { Catalyst, Photography, health } \\
\text { Products and Insecticides }\end{array}$ \\
\hline Semisynthetic resins of chitosan & $\begin{array}{l}\text { Copolymer of chitosan with methyl methacrylate, polyurea-urethane, poly } \\
\text { (amide ester), acrylamidemaleik anhydride }\end{array}$ & Textiles \\
\hline \multirow{7}{*}{$\begin{array}{l}\text { Natural polysaccharide complexes, } \\
\text { miscellaneous }\end{array}$} & Chitosan glucans from various organisms & $\begin{array}{l}\text { Flocculation and metal ion } \\
\text { chelation }\end{array}$ \\
\hline & Alkyl chitin, benzyl chitin, cyanoethyl chitosan & $\begin{array}{l}\text { Intermediate, serine protease } \\
\text { purification }\end{array}$ \\
\hline & Hydroxy butyl chitin, cyanoethyl chitosan & $\begin{array}{l}\text { Desalting filtration, dialysis } \\
\text { and insulating papers }\end{array}$ \\
\hline & Hydroxy ethyl glycol chitosan & $\begin{array}{l}\text { Enzymology, dialysis and } \\
\text { special papers }\end{array}$ \\
\hline & Glutaraldehyde chitosan & Enzyme immobilization \\
\hline & Linoleic acid-chitosan complex & $\begin{array}{l}\text { Food additive and } \\
\text { anticholesterolemic }\end{array}$ \\
\hline & $\begin{array}{l}\text { Uracylchitosan, theophylline chitosan, adenine chitosan, chitosan salts of acid } \\
\text { polysaccharides, chitosan streptomycin, 2-amido-2, 6-diaminoheptanoic acid } \\
\text { chitosan }\end{array}$ & \\
\hline
\end{tabular}




\section{Other applications}

(Table 4) summarizes the possibility employments about chitin and its derivatives owing with their properties (biodegradability, biocompatibility, gel. Forming, and non-toxicity) and living activities (immunological, anti-microbial, and antioxidant) these polysaccharides might a chance to be viewed as concerning illustration another hotspot from claiming productive materials.

Table 4: Principle Properties of chitosan in relation to its use in Bio Medical Applications.

\begin{tabular}{|c|c|}
\hline Potential Biomedical Applications & Principal Characteristics \\
\hline Surgical sutures & Biocompatible \\
\hline Dental implants & Biodegradable \\
\hline Artificial skin & Renewable \\
\hline Rebuilding of Bone & Film Forming \\
\hline Corneal contact lenses & Hydrating agent \\
\hline $\begin{array}{c}\text { Time release drugs for Animals } \\
\text { and Humans }\end{array}$ & Nontoxic, Biological Tolerance \\
\hline $\begin{array}{c}\text { Encapsulating Material } \\
\text { Hydrolyzed by Lyzosyme Wound } \\
\text { healing properties efficient against } \\
\text { bacteria, Viruses, fungi }\end{array}$ \\
\hline
\end{tabular}

\section{Glucans}
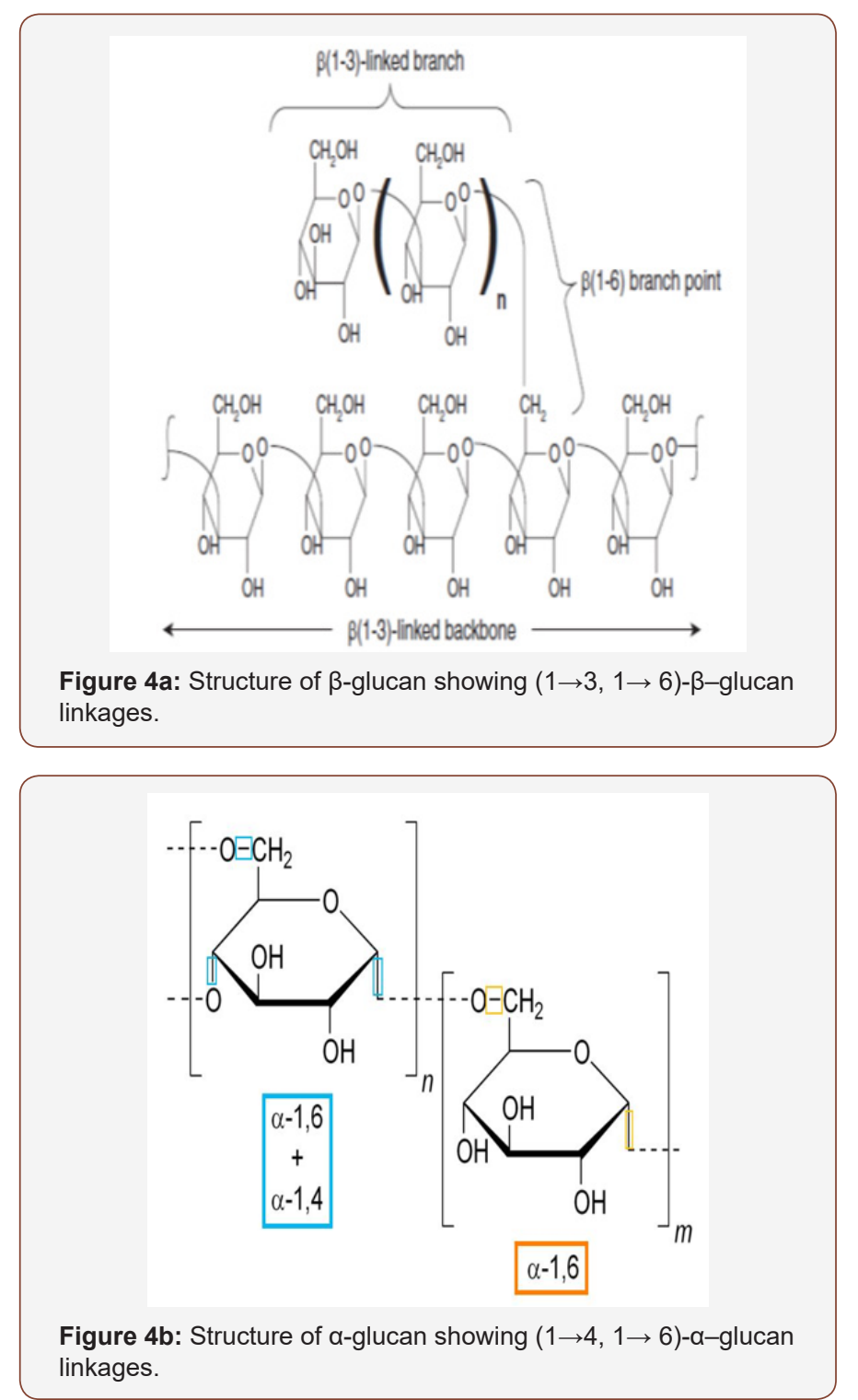

An amount from claiming polysaccharides with $\beta$-glycosidic linkage would broad done way on assorted qualities of wellsprings (fungi, yeast, algae, bacteria also plants). Glucans are glucose polymers with a $\alpha$ - or $\beta$-type glycosidic chain (Figure 4). The macromolecular structure of the glucan relies around both wellspring and the system for isolation. These glucans comprise about straight $(1 \rightarrow 3)$ - $\beta$-linked backbones with whichever $(1 \rightarrow 6)$ e.g., lentinan, laminarin, pleuran or zymosan $(1 \rightarrow 4)$-linked side chains of varying distribution and length e.g., dextran, glycogen, starch, which form complex tertiary structures stabilized via interchain hydrogen bonds. Finally, as stated by their constitution, they need aid specified as homoglycans or heteroglycans $[101,102]$. Those common $(1 \rightarrow 3)-\beta$-D-glucan characterizing parameters involve elementary structure, degree of branching (DB), solubility, furthermore molecular weight (Mw), and additionally those polymers accuse or result conformity (single helix, triple helix, alternately irregular loop conformation). Constantly on these elements assume vital a part over glucan-associated living activity.

(Figure 4) (a) Structure of $\beta$-glucan showing $(1 \rightarrow 3,1 \rightarrow 6)-\beta-$ glucan linkages and (b) Structure of $\alpha$-glucan showing $(1 \rightarrow 4,1 \rightarrow$ 6)- $\alpha$-glucan linkages.

Every last bit needs a regular structure and the $(1 \rightarrow 3)-\beta$-Dglucan spine will be key to their medicinal and bioactive properties. The role of $(1 \rightarrow 3)-\beta-D$-glucan is in the maintenance of yeast cell wall shape and rigidity (Saccharomyces cerevisiae), has been found to improve immune functions. The important benefit of $\beta$-glucan is to enhance the immune system and to reduce LDL and cholesterol levels in the blood in patients with hypercholesterolemia. Several studies have showed the benefits of $\beta$-glucan as: antioxidant, antiinflammatory, antiseptic, anti-aging, immune system activators, protection against radiation, anti-diabetic, anti-cholesterol [3]. Distinctive routines transforming $\beta$-D-glucan on a solvent structure toward evolving or modifying those compound structure, furthermore it brings been distributed. Those $\beta$-D-glucan bioactive properties could make impacted negatively alternately positively by such adjustments. This heterogeneous one assembly about $\beta$-linked polyglucoses will be attracting the climbing consideration about practical nourishment industry and the pharmaceutical due to its sure impacts looking into animal and human health. Cases include medicinal also bioactive properties, for example, antimicrobial, antiinflammatory, hepatoprotective, anti-tumor, immune-stimulation, cholesterol-lowering and in addition anti-diabetic, anti-fibrotic, and hypoglycemic action [103-108]. However, particulate ( $1 \rightarrow 3)-\beta$-Dglucans need been found should a chance to be improper for a lot of people human therapeutic provisions also answerable for critical unfriendly impacts for example, inflammation, pain, granuloma formation, also microembolization, So as will improve $(1 \rightarrow 3)$ - $\beta$-D-glucan solubility, a few derivatization methods for example, carboxy methylation sulfation, and phosphating bring been utilized. Over addition, huge numbers different techniques directing, including basic, furthermore corrosive hydrolysis, ultrasonography irradiation, furthermore enzymatic assimilation have been used to depolymerize those insoluble macromolecular 
structure to prepare underivatized dissolvable $(1 \rightarrow 3)-\beta$-D-glucans. Compound adjustments from claiming $(1 \rightarrow 3)-\beta$-D-glucan could profoundly impact living activity.

\section{Source of glucan}

The sources of glucans are diverse, including.

- $\quad \beta$-Glucan from the fruiting body of fungi [109].

- $\quad \beta$-Glucan from the mycelium of fungi [78].

- $\quad \beta$-Glucan from yeast and seaweed [110].

- $\quad \beta$-Glucan from bacteria [111].

- $\quad \beta$-Glucan-binding protein [111].

- $\quad \beta$-Glucan from cereals [112].

- $\quad \beta$-Glucan from other sources [113].

Therapeutic glucans would generally pick up from edible fungi by boiling also treating with enzymes from a standout amongst those cited sources; glucans might a chance to be concentrated for rough structure yielding dissolvable also insoluble products $[102,114,115]$. There need aid various manifestations of dissolvable $\beta$-glucans investigated for conceivable antitumor activity, for example, such that $(1 \rightarrow 3)-\beta$-D-glucan, SSG got starting with Sclerotina sclerotiorum IFO 9395 [116], SPG (sizofiran, Schizophyllan and sonifilan) starting with Schizophyllum commune [117] and GRN (Grifolan) from Grifola frondosa [118] and they frequently happen concerning illustration an straight triple-helical structure over hydrous result [119]. Insoluble glucans need been disconnected starting with the mushroom lentinus edodes to the initial time [120]. They were also disconnected from the cell wall for yeast toward using the blending from claiming $\mathrm{NaClO}$ oxidation also dimethyl sulfoxide (DMSO) extraction [121]. To enhance their solubility, derivatization via phosphorylation, whichever sulfation alternately amination might make connected. However, insoluble $\beta$-glucans were found will bring higher immunostimulant activity over dissolvable ones and are administered orally. They introduce different sorts from claiming glycosidic bonds beginning Possibly ( $1 \rightarrow 3$ ), $(1 \rightarrow 6)$ - $\beta$-glucans (e.g., zymosan, lentinan, pleuran, laminarin), alternately $(1 \rightarrow 3)-,(1 \rightarrow 4)-,(1 \rightarrow 6)$ - $\alpha$-glucans (e. g., starch, glycogen, dextran). The molecular weight of glucans is dependent upon their extraction method and source [25]. Finally, factors that can greatly affect the application of the glucans are their molecular weight, structure, degree of conformation and branching [122-125]. Such as, the molecular weight of Schizophyllan (SPG), Krestin (PSK), PGG-glucan, and Lentinan, are, respectively, informed as $450,100,170$ and $500 \mathrm{KDa}$ [126-128] (Figure 5).

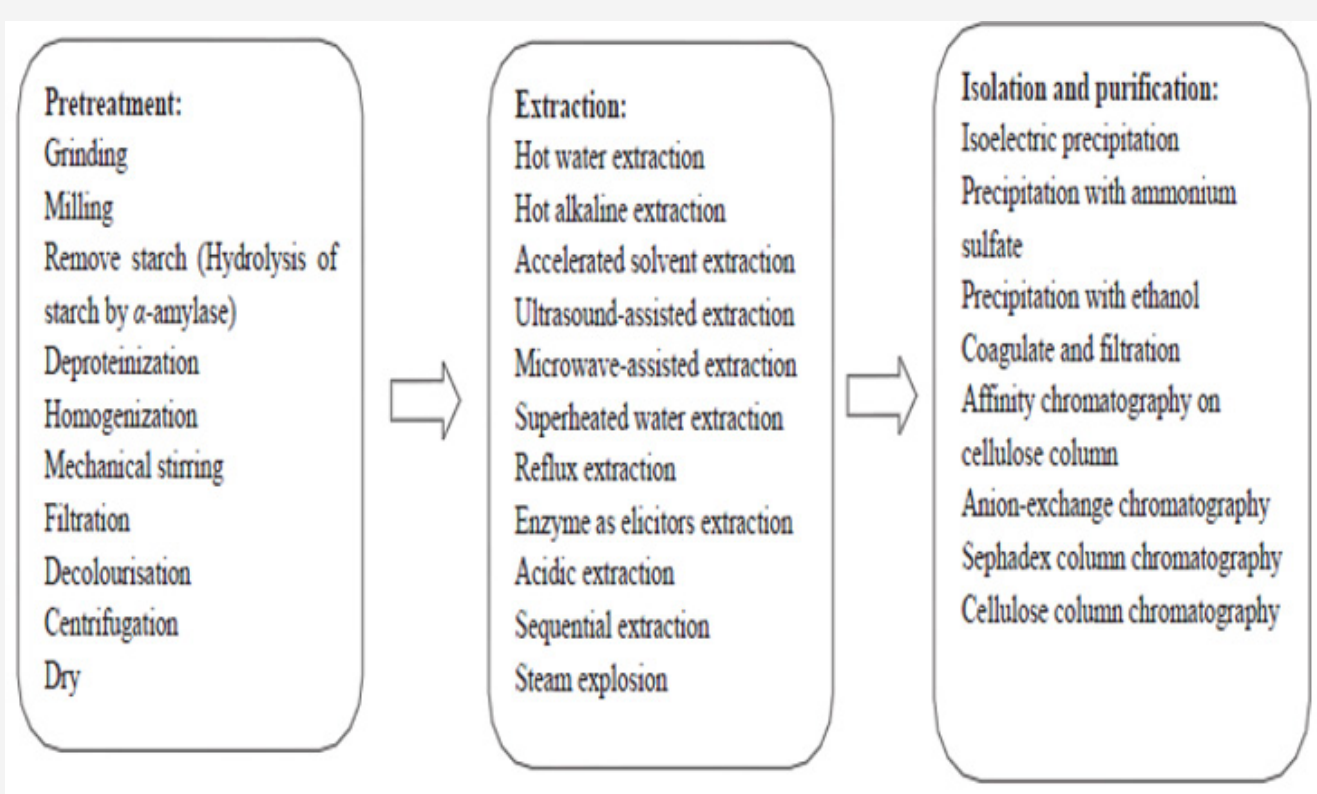

Figure 5: Chart of different steps that may be involved in the extraction and production of $\beta$-glucans in lab scale and pilot plant scale.

\section{Physical and chemical properties of glucans.}

- $\quad$ Structural characteristics.

- Molecular weight.

- Viscosity.

- $\quad$ Helix of glucan (single, double, and triple).

- $\quad$ DP (degree of polymerization.

- $\quad$ Degree of branching.
- $\quad$ The ratio of $\beta-(1 \rightarrow 4) /-(1 \rightarrow 3)$ linkages (linkage ratio).

- $\quad$ Kind of bond in glucan ( $\alpha$ - or/and $\beta$-).

Investigations achieve been directed will inspect those physical properties about $\beta$-glucans [129]. Inspected the physical properties, for example, such that whip ability, foam, viscosity, dependability, furthermore emulsion stabilizing ability of the barley $\beta$-glucan gum should assess possibility sustenance requisitions. The outcomes advertised that most extreme viscosity and emulsion stability were attained at $55{ }^{\circ} \mathrm{C}$ also pH7. Viscosity brought up for $\mathrm{pH}$ at 
consistent temperature. Barley $\beta$-glucan gum shows an incredible possibility likewise a stabilizer alternately thickener to products for example, such that. Sauces, soups, desserts, furthermore Ahmad [130] mixed greens dressings evaluated those part for molecule extent of barley $\beta$-glucan concentrate (BGC) once two generous rheological properties to be specific oscillatory rheology and creep in a batter framework. The effects advertised that the greater part the individual's data might be advantageous should identify the molecule size extent of BGC that might a chance to be supportive to process a $\beta$-glucan enriched arranged nourishment.

Furthermore, Brummer, et al. [131] dead set that those textural, furthermore rheological properties from claiming oat $\beta$-glucan gels with fluctuating molecular weight compositions. Those picked up results indicated that those melting profiles besides textural properties of $\beta$-glucan gum can give us an opportunity to a chance to be manipulated through evolving the proportions over molecular weight portions alternately addition something like sugar for food applications. Liu [132] investigated the effects molecular weight besides structure starting with asserting $\beta$-glucan ahead viscosities starting with guaranteeing oat-flour slurries, the individuals affects from claiming transforming (flaking, moreover steaming) ahead vitro bile acid tying and the viscosities starting with asserting oat-flour pastes were moreover inquired regarding. Those effects advertised that the more stupendous bile acid corrosive tying ability might need been brought about by the $\beta$-glucan structuralmolecular progressions or those improved ability for $\beta$-glucans through climbing accessibility throughout preparing [133].

Those viscosity of the $\beta$-glucan results relies ahead their concentration, structural features, furthermore molecular weight to those structural aspects about $\beta$-glucans, it might have been suggested that the measure from claiming $\mathrm{dp} \geq 5$, proportion for DP3/DP4, and proportion of $\beta-(1 \rightarrow 3) /-(1 \rightarrow 4)$ linkages need aid the huge determinants from solubility also viscosity [134]. Irakli, et al. [135] explored those rheological practices about aqueous dispersions from claiming $\beta$-glucans, particularly as it identifies with their gelation possibility and the impact of included polyols with respect to the textural properties about mixed gels constructed for these Polysaccharides. These discoveries shown that $\beta$-glucans advertised expansive varieties to their stream behavior, gelling ability, furthermore, shear diminishing capacity. The extraction needs exact consideration concerning illustration extraction medication might influence the physiochemical properties of concentrated $\beta$-glucan. Mostly, concentrated pellets required great foaming capacity also water retention. For barley $\beta$-glucan likewise influenced toward different extraction methods a critical variety over extraction systems might have been spotted with admiration to foaming capacity and water tying ability [136]. A paramount sway of extraction procedures might have been additionally spotted on color parameters of $\beta$-glucan. A negative correspondence happens between viscosities also foaming capacity, inasmuch as a sure relationship watched the middle of viscosity and dissolvable fiber. Thammakiti, et al. [137] investigated the impacts of the homogenization for rheological properties, the concoction composition, and practical properties of $\beta$-glucan from baker's yeast. Homogenized yeast cell wall showed higher $\beta$-glucan content and obvious viscosity over the individuals which required not been homogenized due to discontinuity of the cell wall and higher free about $\beta$-glucan. When compared for accepted $\beta$-glucan starting with baker's yeast, it might have been found that those $\beta$-glucan picked up through homogenization needed higher water-holding limit, self-evident viscosity, and emulsion balancing out capacity, yet altogether in oil binding ability those molecular weight values from claiming $\beta$-glucans in oats previously, from $0.35 \times 10^{5}$ wills $29.6 \times 10^{5}$ [137]. Furthermore, rely on upon NMR information and methylation analysis, those ascertained proportions from claiming $\beta-(1 \rightarrow 4) /-(1 \rightarrow 3)$ linkages done oat $\beta$-glucans were inside the range about 1. 9- 2.8 [138]. Those fine structure, molecular weight, conformity, furthermore dissolvability from claiming $\beta$-glucan need been shown will impact living biological activities [103,139,140]. $\beta$-Glucan fine structure also molecular weight, such likewise lengths, $(1 \rightarrow 3)$ will $(1 \rightarrow 6)$ linkage ratio, number and dissemination for cellulosic oligosaccharides will together for nature for coextracted mixes also add up in an $\beta$-glucan preparation impact solubility, polymer conformity also aggravator structuring [141].

\section{Applications of glucans}

$\beta$-Glucans have different physical properties for example, such that emulsification, stabilizing, thickening, and gelation [130]. $\beta$-Glucan need those possibility with make connected previously, to be applied in health products worthy wellbeing results that indicate an extensive variety about included health benefits. There are some of traditional accessible $\beta$-glucans products displayed in Table (5). Many of the enthusiasm toward the utilization of grain $\beta$-glucans need stemmed starting with their utilization concerning illustration a utilitarian dietary fiber [83,142]. $\beta$-Glucans bring possibility provision clinched alongside medication also pharmacy, cosmea, food, concoction industries, on veterinary pharmaceutical $\&$ feed production. Those different applications about $\beta$-glucans are summarized previously in Table (6).

Table 5: Commercially available $\beta$-glucans.

\begin{tabular}{|c|c|c|c|}
\hline Samples & $\begin{array}{c}\text { Biological } \\
\text { Sources }\end{array}$ & Producer & $\begin{array}{c}\text { Molecular } \\
\text { Weight (kDa) }\end{array}$ \\
\hline Oat Glucan & Oat & $\begin{array}{c}\text { Symrise } \\
\text { shanghai Co., } \\
\text { Ltd. }\end{array}$ & 2.5 \\
\hline $\begin{array}{c}\text { Brewer's Yeast } \\
\text { Extract }\end{array}$ & Yeast & $\begin{array}{c}\text { Shanghai Laibo } \\
\text { Biochemical Co., } \\
\text { Ltd. }\end{array}$ & 409 \\
\hline $\begin{array}{c}\text { Cosfa } \\
\text { International } \\
\text { Trading Co., Ltd. }\end{array}$ & 0.2 \\
\hline $\begin{array}{c}\text { Natriance } \\
\text { Brightener Yeast } \\
\text { Extract }\end{array}$ & Yeast & $\begin{array}{c}\text { Shanghai Youth } \\
\text { retain Company }\end{array}$ & 0.2 \\
\hline $\begin{array}{c}\text { Carboxymethyl } \\
\text { Yeast } \beta \text { glucan C90 }\end{array}$ & Yeast & $\begin{array}{c}\text { Angel yeast Co., } \\
\text { company }\end{array}$ & 0.04 \\
\hline $\begin{array}{c}\text { Schizophyllum } \\
\text { Commune Glucan }\end{array}$ & Schizophyllum \\
commune & $\begin{array}{c}\text { Bio land } \\
\text { Technology Co., } \\
\text { Ltd. }\end{array}$ & 604 \\
\hline
\end{tabular}


Table 6: Application of $\beta$-glucans.

\begin{tabular}{|c|c|c|}
\hline Area of Applications & Products & Functionality \\
\hline \multirow{8}{*}{ Foods } & Prebiotic sausage formulation with $\beta$-glucan & Noticeable effect on physician and sensory properties \\
\hline & Gluten-free bread with $\beta$-glucan & Acceptable results of sensory analysis \\
\hline & Dairy products with $\beta$-glucan & Calorie-reduced and cholesterol-lowering \\
\hline & Yogurts with $\beta$-glucan & $\begin{array}{l}\text { Faster proteolysis, lower release of large peptides and a } \\
\text { higher proportion of free amino acids }\end{array}$ \\
\hline & Extruded ready-to-eat snacks & Manipulate the glycemic response \\
\hline & Beverage containing $\beta$-glucan & Control food intake and reduce $24 \mathrm{~h}$ energy intake \\
\hline & Cakes containing $\beta$-glucan & Good quality attributes \\
\hline & Used in food products & $\begin{array}{l}\text { As a thickening, water-holding, or oil-binding agent and } \\
\text { emulsifying stabilizer }\end{array}$ \\
\hline \multirow{7}{*}{ Medicines } & Wound dressing material & Larger inner cavity diameter \\
\hline & transparent wound dressing sheet & $\begin{array}{l}\text { Therapeutic efficacies comparable or superior to a } \\
\text { commercial wound dressing }\end{array}$ \\
\hline & Curing partial-thickness burns & Decrease post injury pain \\
\hline & Curing burn-induced remote organ injury & Be effective against burn-induced oxidative tissue damage \\
\hline & Poly-membranes containing $\beta$-glucan & Accelerated wound healing effects \\
\hline & A bone substituting material & $\begin{array}{l}\text { Easy manipulation and good adaptation to the shape and } \\
\text { dimensions of even large bone defects }\end{array}$ \\
\hline & Vaccine delivery platform & Can be exploited for vaccine development \\
\hline \multirow{8}{*}{ Cosmetics } & Film-forming moisturizer & Efficacy for reducing fine lines and wrinkles \\
\hline & Skin and dermatological compositions & $\begin{array}{l}\text { Moisturization of skin or mucosa and anti-aging and } \\
\text { revitalizing effect on the skin }\end{array}$ \\
\hline & Cosmetic product & $\begin{array}{l}\text { Defer skin aging, impact skin whitening effect and cure } \\
\text { skin damage effectively }\end{array}$ \\
\hline & Cosmetic product & Treat collagen loss in aging skin \\
\hline & Cosmetic formulation containing CM $\beta$-glucan & With good spread ability and skin smoothing effect \\
\hline & Emulsion containing CM $\beta$-glucan & Improve skin condition \\
\hline & Cosmetic product containing yeast $\beta$-glucan & Enhance ulcer healing and increase epithelia hyperplasia \\
\hline & Eye drops with mushroom $\beta$-glucan & Great moisture retention \\
\hline \multirow[b]{2}{*}{ Feeds } & Animal feed additive & Enhance immunity and as a potential antitumor agent \\
\hline & Fish feed additive & $\begin{array}{l}\text { Increase the number of specific antibody secreting cells } \\
\text { and specific lg levels in serum }\end{array}$ \\
\hline \multirow{5}{*}{ Other health products } & Materials for health foods & Useful \\
\hline & Personal care compositions containing $\beta$-glucan & Hair care actives \\
\hline & Novel prebiotics & Health-promoting property \\
\hline & $\beta$-glucan nanoparticles & $\begin{array}{l}\text { Exhibit antifungal activity against Pythium } \\
\text { aphanidermatum }\end{array}$ \\
\hline & Nutraceutical product containing $\beta$-glucan & Useful \\
\hline
\end{tabular}

Applications in foods: A sort from claiming ascent levels from claiming $\beta$-glucan might have been picked up starting with barley or oat grain. This result cam wood a chance to be processed likewise an agglomerate sustenance added substance hosting in any event regarding $18 \% \beta$-glucan by means of dry weight. Techniques are giving to enriching an item with that $\beta$-glucan agglomerate sustenance added substance optimized those prebiotic hotdog plan via means of safe starch, $\beta$-glucan furthermore starch as stated by optimal mixture configuration methodology $[143,144]$. $\beta$-Glucan required observable impact around tangible properties, furthermore physical for hotdog. Similarly as a result, the handling about prebiotic hotdog utilizing mix from claiming safe starch and $\beta$-glucan will be could be allowed [145] investigated those impacts for hydroxypropyl methylcellulose, yeast $\beta$-glucan, and whey protein disconnect ahead physical properties for gluten-free bread heated starting with formulas relies once rice starch. As a consequence, the optimized rice starch bread figured for yeast $\beta$-glucan might have been found with make suitability as stated by those comes about of tactile examination Additionally, Sharafbafi, et al. [146]. integrated high molecular size of oat $\beta$-glucan under drain to get calorie-lowered and cholesterol- diminishing dairy products, and the stage behavior, microstructure, furthermore rheological properties, from claiming this dairy item were broke down. The outcomes advertised that those stream conducts of the mixtures for focuses higher over the binodal bend might have been not best legislated through the vicinity about $\beta$-glucan chains, as well as through the framing about these structures. Additionally, Rinaldi, et al. [147] found that yogurts held with $\beta$-glucan and with pectin 
shown a speedier proteolysis, an easier free of huge peptides, and a higher extent for spare amino acids over the individuals for starch alternately without $\beta$-glucan. Discrimination between $\beta$-glucan, furthermore dairy proteins might have been guessed should explain speedier proteolysis through centralization from claiming proteins and proteins previously, a divided period. It need been shown that $\beta$-glucan riches portions starting with mushroom and barley connected in the creation of extruded ready-to-eat snacks. Those comes about shown that the consideration from claiming these portions might a chance to be utilized toward the food industry should control those glycemic reaction of extruded snack products [148]. Assessed those satiating ability about three drinks holding barley $\beta$-glucan, alternately dry flour (DF) from fruit, or without DF. The outcomes shown that suction sweetened refreshment given $3 g$ barley $\beta$-glucans might control sustenance admission complex also it might indeed diminish $24 \mathrm{~h}$ vitality admission complex. Kim, et al. [149] prepared the $\beta$-glucan-enriched materials starting with mushroom lentinans eddoes as a wheat flour substitute that might make effectively connected to prepare cakes holding $1 \mathrm{~g}$ from claiming $\beta$-glucan for every serving with nature qualities in to the individuals of the control Lazaridou, et al. [138]. The physiological effects from claiming barley rusks might have been evaluated by means of measuring that viscosity of the rusk extract and the measure about solubilized $\beta$-glucans. Both autoclaving and rising flour molecule span fundamentally $(p<0.05)$ raised those viscosity of the rusk physiological extracts. to explain faster proteolysis via proteins in a separated phase and concentration of enzymes. It has been indicated that $\beta$-glucan riches portions starting with mushroom and barley connected in the preparation from claiming extruded ready-to-eat snacks. Those outcomes offered that those considerations for these portions might be used via the nourishment industry will control the glycemic reaction for extruded snack products [148].

Applications in medicines: There is a most recent survey around clinical trials on the wellbeing useful impacts from claiming oral organization from claiming $\beta$-glucan arrangements [141]. $\beta$-glucans have been applied in various clinical trials should test their all impacts around elucidate those components capable, furthermore health applied [150]. Venkatachalam, et al. [151] cyclic glucans as wound dressing material owing to cyclic glucans need bigger inward pit breadth. Moreover, Kofuji, et al., [152] picked up a transparent wound dressing sheet through forming a complex between chitosan and $\beta$-glucan. The comes about specified that $\beta$-glucan chitosan mind boggling sheet might have been a guaranteeing up to date wound dressing result [153]. It is found that partial-thickness blazes over know youngsters might make effectively approached for $\beta$-glucan for beneficial results, indeed previously, little children, furthermore babies. $\beta$-Glucan markedly streamlined wound administers to crew and the tolerant and appeared with vitally diminish post harm agony. $\beta$-Glucans point thought similarly as restorative operators in the medication about wound recuperating, furthermore, blaze damages [154]. Furthermore, over one study, those putative protective impacts of $\beta$-glucan medicine with respect to burn-induced remote organ harm might have been scrutinized. Those outcomes indicated that organization from claiming $\beta$-glucan were successful against burn-induced oxidative tissue damage in the rats [154]. On another study, Kim, et al. [149] investigated wound-healing impacts of the poly (lactic-co-glycolic acid) membranes holding $\beta$-glucan, the discoveries shown that the membranes quickened wound recuperating via upgrading the interaction, angiogenesis, and proliferation of cells. Therefore, these membranes cam wood be gainful concerning illustration a skin substitute for moving forward wound recuperating. Previously, another later contemplates by, Sakurai, et al. [155] shown that those curdlan sulfates for dry starch (DS) from 1. 7 will 8. 7\% Might type complexes with polyketidic corrosive in the same way similarly as schizophyllan. The unpredictable polynucleotide chain advertised a critical imperviousness against enzymatic hydrolysis. It need been expected that these water-soluble sulfated curdlan nucleotide complexes might figure requisition previously, gene innovation clinched alongside medication. This study might have been on get ready a biphasic hydroxyapatite/glucan composite of versatile properties, which might tolerance to not difficult control and handy adjustment of the state also extents about Indeed going extraordinary bone defects. The effects demonstrated that adaptable hydroxyapatite/ glucan composite needed possibility similar to a bone substituting material [156]. Moreover, Kogan, et al. [157] discovered that the radical searching movement from claiming carboxymethylated $\beta$-glucan in the in-vivo analyses. They spotted a considerable slide in the level of plasmatic carbonyls. It might have been supposed that carboxymethylated $\beta$-glucan radical-scavenging properties might be answerable for those antioxidant activities in the adjuvant joint inflammation model. This acquires the contract for time permits medicinal provisions from claiming this glucan subordinate done joint arthritis medicine. Moreover, a principle challenge previously, vaccinology will be those improvement about adjuvant, furthermore platforms that efficiently push protective lymphocyte and immunizer reactions. Levitz [158] connected $\beta$-glucan likewise another immunization stage. $\beta$-Glucan might make stacked for antigens and immunomodulators such-and-such those "payload" may be liberated emulating phagocytosis. They bring demonstrated strong, furthermore enduring antigen-specific white blood cell also immunizer reactions accompanying inoculation from claiming mice with $\beta$-glucan "encapsulated" for immunizer.

Applications in cosmetics: $\beta$-Glucan need been connected as a rule ointment, protective creams, suspensions, furthermore, powders to a few decades. An imputed action from claiming $\beta$-glucan assuming that its ascents collagen production, also declines. Age lines, wrinkles, crow's feet, cellulite, dermatitis, psoriasis, eczema, acne, and also other skin states. It might have been discovered that $\beta$-glucan is a film-forming moisturizer and a promoter for wound recuperating [159]. Discovered that those infiltration about oat $\beta$-glucan in human skin models, furthermore with evaluate clinically its viability to diminishing fine-lines also wrinkles. The effects specified that $\beta$-glucan profoundly penetrated the skin under 
the epidermis and dermis. Investigate helps the use of $\beta$-glucan in the forethought and the cosmea medicine of the indications for maturing and upkeep from claiming health skin [160]. Chen [161] one considers advertised that a low focus of a particular polysaccharide of the scleroglucan population may be advantageous in the field from claiming skin, furthermore dermatological compositions. Those glucan piece demonstrated invaluable effects, for example, such that mucosa alternately moisturization from claiming skin, and need an anti-aging, furthermore revitalizing impact on the skin discovered a mushroom glucan need secondary dampness maintenance and could a chance to be connected for eye drops for alleviating xerophthalmia. Additionally, Du, et al. [142] indicated the skin wellbeing advancement impacts about regular $\beta$-glucan inferred starting with microorganisms also cereals [162]. Acquired a $\beta-(1 \rightarrow 6)$-branched- $\beta-(1 \rightarrow 3)$-glucan starting with fluid mycelia culture from $\mathrm{S}$. commune. The picked-up Outcomes demonstrated that this glucan cam wood delay skin aging, confer skin whitening impact and cure skin mischief viably Ketkeaw, et al., [163]. Found that a $\beta$-glucan from heave latex brought up fibroblast collagen generation likewise contrasted with control. Comes about suggested that conceivable requisition of Heave $\beta$-glucan for medication including collagen lack aging skin. Vacharaprechakul, et al., [164] figured a sort about cosmetician holding brewer's yeast carboxy methyl glucan (CM - glucan). The stability and predilection might have been analyzed also might have been clinically examined. It might have been stated that the plan holding $0.1 \%$ about CM-glucan might have been stable with immaculate spread capability and skin calming impact. Kanlayavattanakul \& Lourith [165] elucidated that anti-wrinkle viability of 0. 04\% CM-glucan previously, an emulsion using testing with respect to 10 volunteers age-old through 60 a long time through double everyday requisition around eyes, furthermore lower arm. The effects shown that those 0.04\% CM-glucan emulsion altogether improved skin condition inside 28 times such as those skin might have been firmer, and the eye wrinkle profundity might have been diminished. To An investigation by Medeiros, et al. [166], those impacts of the $\beta$-glucan starting with that dough baker's yeast with respect to wound recuperating were assessed for human venous ulcers. Likewise, a result, $\beta$-glucan improved ulcer recuperating also raised epithelial hyperplasia, and additionally raised angiogenesis, incendiary cells, and fibroblast burgeoning.

Applications of glucan in other health products: Suzuki, et al. [167] found a sort from claiming $\beta-(1 \rightarrow 3)-(1 \rightarrow 6)$-D-glucan which might have been useful to materials for wellbeing nourishments getting starting with those society medium holding $\beta$-glucan, which an microorganism having a place to Aureobasidium $s p$. produces extracellularly. Additionally, Mitra [168] scrutinized those private issue compositions holding hair and healthy skin actives for example, such that $\beta$-glucans. Such compositions would supportive for managing. The state for mammalian keratinous tissue expecting such medicines, newly, the greater part about prebiotics in the businesses would go starting with non-digestible oligosaccharides. Those $\beta$-glucan needs been notified to make connected with a number health-promoting and prebiotic properties. Lam and Cheung [169] explored the possibility of long chain $\beta$-glucans with serve concerning illustration new prebiotics rely on upon present information around their sources, fermentation, preparation, characteristics, and the possible components included in the usage. Anusuya \& Sathiyabama [170] clarified those preparations from claiming $\beta$-glucan (isolated starting with that cell divider of Pythium aphanidermatum) nanoparticles throughout s were as for sodium hydroxide on $\beta$-glucan result with consistent blending during $90{ }^{\circ} \mathrm{C}$. Moreover, the readied nanoparticles indicated antifungal movement against p. Aphanidermatum. Camelini, et al. [171] Scrutinized those $\beta$-glucans from agaricus brasiliensis previously, different phases from claiming fruiting body development and their use done nutraceutical results. Those comes about advertised that full-grown fruiting figures of $a$. Brasiliensis ought to make connected to nutraceutical items to they hold these critical glucans. Cap-opened, a greater amount delicate full-grown fruiting figures of $a$. Brasiliensis if it chose again adolescent ones for those creation of nutraceuticals.

Applications of glucans in feed industry: $\beta$-Glucans need been processed not just in the sustenance also, pharmaceutical commercial enterprises likewise immunomodulating agents, also, anticancer at in the animals and aquaculture commercial enterprises for enhancing those characteristic resistance for animals [172]. Gathered that the $\beta$-glucan produced from Paenibacillus polymyxa JB115 was might a chance to be connected as a creature encourage added substance to the reason for enhancing resistance. Furthermore, rainbow trout (Oncorhynchus mykiss) were nourished pellets holding $\beta$-glucan toward at dose from claiming $0.5 \%$ about pellets for every day. Those effects discovered that $\beta$-glucan ascent those amount from claiming particular immunizer secreting and particular immunoglobulin (Ig) levels over serum [173]. Mushrooms are known for their immune modulating influence for which the polysaccharide fraction, mostly glucans, seems to be responsible. Fungal $\beta$-glucans have been investigated extensively, whereas little is known about mushroom $\alpha$-glucans. Volman, et al. [174] have earlier offered that the polysaccharide fraction from the mushroom A. bisporus, consisting $90 \%$ of $\alpha$-glucans, induced in vitro nitric oxide and tumor necrosis factor (TNF) production. The absence of vigorous immune modulating influence on peripheral mononuclear blood cells (PBMCs) might pertain to the comparable structure of $\alpha$-glucan with amylose. It is known that these compounds can be digested in vivo via $\alpha$-amylases that are presence in pancreatic juice and saliva. Therefore, our current finding purposes that in the in vivo situation, $\alpha$-glucans have lost their effectiveness to invigorate the systemic immune response spotted in our in vitro mouse model. Moreover, it cannot be excluded that $\beta$-glucans have only local influences in the intestine, which are not reflected in systemic PBMC behavior.

\section{Conclusion}

In this review, properties (chemical also physical) of glucan, chitin and chitosan are value vehicles that meet the needs 
of consumers for natural and inexpensive products, which had a positive impact on health [175-182]. There is complete agreement in the interest of these polysaccharides because of their attractive properties of biocompatibility, biodegradability, non-toxicity and solubility required to process polysaccharides for the novel material, which may be useful for new applications possible. Therefore, it can be applied in large range of industrial and pharmaceutical applications (anti-bacterial, anti-fungal, radical scavenging, anti-oxidant, anti-tumor, cardiovascular, antihypercholesterolemia, anti-aging, anti-inflammatory, anti-viral, anti-parasitic, detoxification, hepatoprotective, hemostasis, wound healing, and immunomodulating), pharmaceuticals, agriculture, foods, nutraceutical products, cosmetics, textiles, paper making, and enzymes-immobilization, besides these applications they also are eco-friendly. Recently a promising approach (nanotechnology) is the enhancement and exploration of polysaccharide depend on functional nanomaterials (biocompatibility, hydrophilic, water swelling ratio by electrostatic interactions) in different field of applications.

\section{Acknowledgement}

None.

\section{Conflict of Interest}

\section{No conflict of interest.}

\section{References}

1. Lower SE (1984) Polymers from the sea chitin and chitosan. Manuf Chem 55: 73-5.

2. Skaugrud O, Sargent G (1990) Chitin and chitosan: crustacean biopolymers with potential application. International By-products Conference, Anchorage Alaska P. 61-72.

3. Panchakshari V, Srikanth KP, Krishnaand V, Suresh Babu Ch (2016) Extraction of Chitin and Chitosan from Biowaste ofScampi Macrobrichum rosenbergii and Tiger Shrimp Penaeus monodon. Int J Curr Microbiol App Sci 5(7): 751-758.

4. Rinaudo M (2006) Chitin and chitosan: properties and applications. Progress in Polymer Science 31(7): 603-632.

5. Rinaudo M (2008) Main properties and current applications of some polysaccharides as biomaterials Polym Int 57: 397-430.

6. Rinaudo M (2012) Physical properties of chitosan and derivatives in sol and gel states. In Chitosan-Based Systems for Biopharmaceuticals: Delivery, Targeting and Polymer Therapeutics; Sarmento, B, das Neves J, Eds.; John Wiley \& Sons: Chichester, UK, pp. 23-44.

7. Rinaudo M (2014) Materials based on chitin and chitosan. In Bio-Based Plastics: Materials and Applications; Kabasci, S., Ed.; John Wiley \& Sons: Chichester, UK, pp. 63-80.

8. Nitar N, Tetsuya Furuike, Hiroshi T (2011) Production, Properties and Applications of Fungal Cell Wall Polysaccharides: Chitosan and Glucan. Adv Polym Sci 244: 187-208.

9. Zvezdova D (2010) Synthesis and characterization of chitosan from marine sources in black sea. Scientific Works of the Rousse University by Bulgaria 49: 65-69.

10. Blackwell J (1973) Chitin. In Biopolymers, Walton AG, Blackwell J, (Eds), New York, USA. pp: 474-489.

11. Rudall KM, Kenchington W (1973) The chitin system. Biol Rev 40: 597636.

12. Helbert W, Sugiyama J (1998) High-resolution electron microscopy on cellulose II and $\alpha$-chitin single crystals. Cellulose 5(2): 113-122.
13. Persson JE, Domard A, Chanzy H (1990) Single crystals of a-chitin. Int J Biol Macromol 14(4): 221-224.

14. Bartnicki Garcia S, Persson J, Chanzy H (1994) An electron microscope and electron diffraction study of the effect of calcofluor and congo red on the biosynthesis of chitin in vitro. Arch Biochem Biophys 310: 6-15.

15. Ruiz-Herrera,J, Sing VO, van der Woude WJ, Bartnicki-Garcia S (1975) Micro fibril assembly by granules of chitin synthetase. Proc Natl Acad Sci USA, 72: 2706-2710.

16. Sakamoto J, Sugiyama J, Kimura S, Imai T, Itoh T, et al. (2000) Artificial chitin spherulites composed of single crystalline ribbons of $\alpha$-chitin via enzymatic polymerization. Macromolecules 33: 4155-4160.

17. Rudall KM (1969) Chitin and its association with other molecules. J Polym Sci Part C 28: 83-102.

18. Gaill F, Persson J, Sugiyama P, Vuong R, Chanzy H (1992) The chitin system in the tubes of deep-sea hydrothermal vent worms J Struct Biol 109(2): 116-128.

19. Kurita K, Tomita K, Ishi S, Nishimura SI, Shimoda K (1993) $\beta$-chitin as a convenient starting material for acetolysis for efficient preparation of N-acetylchitooligosaccharides. J Polym Sci a Polym Chem 31: 23932395.

20. Park PJ, Je JY, Kim SK (2003) Free radical scavenging activity of chitooligosaccharides by electron spin resonance spectrometry. J Agric Food Chem 51(16): 4624-4627.

21. Yin XQ Lin $Q$, Zhang $Q$ Yang LC (2003) 02- scavenging activity of chitosan and its metal complexes. Chin J Appl Chem 19: 325-328.

22. Kim KW, Thomas RL (2007) Antioxidative activity of chitosans with varying molecular weights. Food Chemistry 101(1): 308-313.

23. Je JY, Park PJ, Kim SK (2004) Free radical scavenging properties of hetero-chitooligosaccharides using an ESR spectroscopy. Food Chem Toxicol 42(3): 381-387.

24. Atkins EDT (1985) information in polysaccharides and complex carbohydrates. J Biosci 8: 375-387.

25. Minke R, Blackwell J (1978) The structure of $\beta$-chitin. J Mol Biol 120: 167-181.

26. Brugnerotto J, Lizardi J, Goycoolea FM, Arguelles Monal W, Desbrieres J, et al. (2001) An infrared investigation in relation with chitin and chitosan characterization. Polymer 42(8): 3569-3580.

27. Kono H (2004) Two-dimensional magic angle spinning NMR investigation of naturally occurring chitins: Precise $1 \mathrm{H}$ and $13 \mathrm{C}$ resonance assignment of $\alpha$ - and $\beta$-chitin. Biopolymers 75(3): 255-263.

28. Tanner SF, Chanzy H, Vincendon M, Roux JC, Gaill F, et al. (1990) High resolution solid-state carbon-13 nuclear magnetic resonance study of chitin. Macromolecules 23: 3576-3583.

29. Poirier M, Charlet G (2002) Chitin fractionation and characterization in $\mathrm{N}, \mathrm{N}$-dimethylacetamide/ lithium chloride solvent system. Carbohydr. Polym 50(4): 363-370.

30. Terbojevich M, (1988) Solution studies of the chitin-lithium chloride-N, N-dimethylacetamide system. Carbohydr Res 180: 73-86.

31. Pillai CKS, Paul W, Sharma CP (2009) Chitin and chitosan polymers: chemistry, solubility and fiber formation. Progress in Polymer Science 34(7): 641-678.

32. Rinaudo M, Domard A (1989) Solution properties of chitosan. In Chitin and Chitosan; Skjak-Bræk, G., Anthonsen, T., Stanford, P., Eds.; Kluwer Academic Publisher: Dordrecht, the Netherlands, pp. 71-86.

33. Aiba SI (1991) Studies on chitosan: evidence for the presence of random and block copolymer structures in partially $\mathrm{N}$-acetylated chitosans. International Journal of Biological Macromolecules 13: 40-44.

34. Berger J, Reist M (2005) Pseudo-thermosetting chitosan hydrogels for biomedical application. Int J Pharm 28: 197-206.

35. Rong HC, Hwa HD (1996) Effect of molecular weight of chitosan with the same degree of deacetylation on the thermal, mechanical, and permeability properties of the prepared membrane. Carbohydr Polym 29(4): 353-358. 
36. Dutta PK, Dutta J, Tripathi VS (2004) Chitin and chitosan: chemistry, properties and applications. Journal of Scientific \& Industrial Research 63: 20-31.

37. Arguelles Monal W, Goycoolea FM, Peniche C, Higuera Ciapara I (1998) Rheological study of the chitosan/glutaraldehyde chemical gel system. Polymer Gels Networks 6: 429-440.

38. Shen X, Tong H, Jiang T, Zhu Z, Wan P, et al. (2007) Homogeneous chitosan/ carbonate apatite/citric acid nanocomposites prepared through a novel in situ precipitation. Compos Sci Technol 67: 2238-2245.

39. Yokoyama A, Yamamoto S, Kawasaki T, Kohgo T, Nakasu M, et al. (2002) Development of calcium phosphate cement using chitosan and citric acid for bone substitute materials. Biomaterials 23: 1091-1101.

40. Hirano S, Yamaguchi R, Fukui N, Iwata M (1990) A chitosan oxalate gel: Its conversion to an $\mathrm{N}$-acetylchitosan gel via a chitosan gel. Carbohydr Res 201(1): 145-149.

41. Yamaguchi R, Hirano S, Arai Y, Ito T (1978) Chitosan salt gels thermally reversible gelation of chitosan. Agric Biol Chem 42: 1981-1982.

42. Desai KGH, Park HJ (2005) Encapsulation of vitamine C in tripolyphosphate cross-linked chitosan microspheres by spray drying. J Microencapsul 22(2): 179-192.

43. Rinaudo M, Quemeneur F, Pepin-Donat B (2009) Stabilization of liposomes against stress using polyelectrolytes: Interaction mechanisms, influence of $\mathrm{pH}$, molecular weight, and polyelectrolyte structure. Int J Polym Anal Charact 14: 667-677.

44. Boddohi S, Killingsworth CE, Kipper MJ (2008) Polyelectrolyte multilayer assembly as a function of $\mathrm{pH}$ and ionic strength using the polysaccharides chitosan and heparin. Biomacromolecules 9(7): 2021-2028.

45. Haidar ZS, Hamdy RC, Tabrizian M (2008) Protein release kinetics for core-shell hybrid nanoparticles based on the layer-by-layer assembly of alginate and chitosan on liposomes. Biomaterials 29(9): 1207-1215.

46. Hillberg AL, Tabrizian M (2006) Biorecognition through layer-bylayer polyelectrolyte assembly: In situ hybridation on living cells. Biomacromolecules 7(10): 2742-2750.

47. Chung TW, Yang J, Akaike T, Cho KY, Nah JW, et al. (2002) Preparation of alginate/galactosylated chitosan scaffold for hepatocyte attachment. Biomaterials 23(14): 282-283.

48. Iwasaki N, Yamane ST, Majima T, Kasahara Y, Minami A, et al. (2004) Feasibility of polysaccharide hybrid materials for scaffolds in cartilage tissue engineering: Evaluation of chondrocyte adhesion to polyion complex fibers prepared from alginate and chitosan. Biomacromolecules 5(3): 828-823.

49. Majima T, Funakosi T, Iwasaki N, Yamane ST, Harada K, et al. (2005) Alginate and chitosan polyion complex hybrid fibers for scaffolds in ligament and tendon tissue engineering. J Orthopaedic Sci 10(3): 302307.

50. Alameh MZ, Jean M, Dejesus D, Buschmann MD, Merzouki A (2015) Chitosanase-based method for RNA isolation from cells transfected with chitosan/siRNA nanocomplexes for real-time RT-PCR in gene delivery. Int J Nanomedecine 5: 473-481.

51. Jean M, Smaoui F, Lavertu M, Méthot S, Bouhdoud L, et al. (2009) Chitosan-plasmid nanoparticle formulations for IM and SC delivery of recombinant FGF-2 and PDGF-BB or generation of antibodies. Gene Therapy: 16(9): 1097-1110.

52. Lavertu M, Méthot S, Tran-Khanh N, Buschmann MD (2006) High efficiency gene transfer using chitosan/DNA nanoparticles with specific combinations of molecular weight and degree of deacetylation. Biomaterials 27(27): 4815-4824.

53. Strand SP, Danielsen S, Christensen BE, Varum KM (2005) Influence of chitosan structure on the formation and stability of DNA-Chitosan polyelectrolyte complexes. Biomacromolecules 6: 3357-3366.

54. Thibault M, Nimesh S, Lavertu M, Buschmann M (2010). Intracellular trafficking and decondensation kinetics of chitosan-pDNA polyplexes. Mol Ther 18: 1787-1795.
55. Venter JP, Kotze AF, Auzely-Velty R, Rinauda M, et al. (2006) Synthesis and evaluation of mucoadhesivity of $\mathrm{CD}$-chitosan derivative. International Journal of Pharmaceutical 313: 36-42.

56. Younes I, Rinaudo M (2015) Chitin and chitosan preparation from Marine sources. Structure, properties and applications. Marine Drugs 13: 1133-1174.

57. Farkas V (1990) Fungal cell walls: Their structure, biosynthesis and biotechnological aspects. Acta Biotechnol 10(3): 225-238.

58. Fleet GH, Phaff HJ (1981) Fungal glucans-structure and metabolism. Plant Carbohydrates II, pp. 416-440.

59. Alishahi A, Aider M (2012) Applications of chitosan in the seafood industry and aquaculture: A review. Food Bioprocess Technol 5: 817830.

60. Friedman M, Juneja VK (2010) Review of Antimicrobial and Antioxidative Activities of chitosans in Food. J Food Prot 73(9): 1737-1761.

61. Kardas I, Struszczyk MH, Kucharska M, van den Broek LAM, van Dam JEG, et al. (2012) Chitin and chitosan as functional biopolymers for industrial applications. In the European Polysaccharide Network of Excellence (EPNOE). Research Initiatives and Results, Narvard P, Edn Springer-Verlag: Wien, Austria, pp. 329-374.

62. Bordenave N, Grelier S, Cama V (2007) Water and moisture susceptibility of chitosan and paper-based materials: Structure-property relationships. J Agric Food Chem 55(23): 9479-9488.

63. Zhang N, Andresen BT, Zhang C (2010) Inflammation and reactive oxygen species in cardiovascular disease. World Journal of Cardiology 2: $408-410$.

64. Cui H, Kong Y, Zhang H (2012) Oxidative stress, mitochondrial dysfunction, and aging. J Signal Transduct pp:1-13.

65. Filippin LI, Vercelino R, Marroni NP, Xavier RM (2008) Redox signaling and the inflammatory response in rheumatoid arthritis. Clinical \& Experimental Immunology 152(3): 415-422.

66. Manda G, Nechifor MT, Neagu TM (2009) Reactive oxygen species, cancer and anti-cancer therapies. Current Chemical Biology 3(1): 342-366.

67. Wysokowski M, Petrenko I, Stelling AL, Stawski D, Jesionowski T, et al. (2015) Poriferan chitin as a versatile template for extreme biomimetics. Polymers 7: 235-265.

68. Park BK, Kim MM (2010) Applications of chitin and its derivatives in biological medicine. International Journal of Molecular Sciences 11(12): 5152-5164.

69. Kerch G (2015) The potential of chitosan and its derivatives in Prevention and treatment of age-related diseases. Marine drugs 13(4): 2158-2182.

70. Harish KV, Tharanathan RN (2007) Chitin/chitosan: modifications and their unlimited application potential-an overview. Trends in Food Science \& Technology 18(3): 117-131.

71. Tharanathan RN, Kittur FS. (2003) Chitin-the undisputed biomolecule of great potential. Critical Reviews in Food Science and Nutrition 43: 61-87.

72. Barikani M, Oliaei E, Seddiqi H, Honarkar H (2014) Preparation and application of chitin and its derivatives: a review. Iranian Polymer Journal 23: 307-326.

73. Sethulekshmi C (2014) Chitin and its benefits. International Journal of Advanced Research in Biological Sciences 1: 171-175.

74. Khoushab F, Yamabhai M (2010) Chitin research revisited. Mar Drugs 8(7): 1988-2012.

75. El-Diasty EM, Nesreen Z, Hoda AM (2012) Using of chitosan as antifungal agent in kariesh cheese. New York Science Journal 5: 5-10.

76. Muzzarelli RAA, Muzzarelli C (2005) Chitosan chemistry: relevance to the biomedical sciences. Advances in Polymer Science 186: 151-209.

77. Aranaz I, Mengibar M, Harris R, Panos I, Miralles B, et al. (2009) Functional characterization of chitin and chitosan. Current Chemical Biology 3: 203-230. 
78. Sinha S, Chand S, Tripathi P (2014) Microbial degradation of chitin waste for production of chitosanase and food related bioactive compounds. Applied Biochemistry and Microbiology 50: 125-133.

79. Dutta J, Tripathi S, Dutta PK (2012) Progress in antimicrobial activities of chitin, chitosan and its oligosaccharides: a systematic study needs for food applications. Food Science and Technology International, 18(1): 3-34.

80. Park H, Ka KH, Ryu SR (2014) Enhancement of b-glucan content in the cultivation of cauliflower mushroom (Sparassis latifolia) by elicitation. Mycobiology 42(1): 41-45.

81. Xia W, Liu P, Zhang J, Chen J (2010) Biological activities of chitosan and chitooligosaccharides. Food Hydrocolloids 25: 170-179.

82. Morganti P, Morganti G, Morganti A (2011) Transforming nanostructured chitin from crustacean waste into beneficial health products: a must for our society. Nanotechnology, Science and Applications 4: 123-129.

83. Arvanitoyannis IS (2008) The use of chitin and chitosan for food packaging applications. In E Chiellini (Ed.), Environmentally compatible food packaging. pp. 137-157.

84. Dash M, Chiellini F, Ottenbrite RM, Chiellini E (2011) Chitosan-a versatile semi-synthetic polymer in biomedical applications. Progress in Polymer Science 36(8): 981-1014.

85. Bansal V, Kumar Sharma P, Sharma N, Prakash Pal O, Malviya R (2011) Applications of chitosan and chitosan derivatives in drug delivery. Advances in Biological Research 5: 28-37.

86. Coelho JF, Ferreira PC, Alves P, Cordeiro R, Fonseca AC, et al. (2010) Drug delivery systems: advanced technologies potentially applicable in personalized treatments. EPMA Journal 1(1): 164-209.

87. Sinha VR, Singla AK, Wadhawan S, Kaushik R, Kumria R, et al. (2004) Chitosan microspheres as a potential carrier for drugs. International Journal of Pharmaceutics 274: 1-33.

88. Kavitha K, Keerthi TS, Tamizh Mani T (2011) Chitosan polymer used as carrier in various pharmaceutical formulations: brief review. International Journal of Applied Biology and Pharmaceutical Techology 2(2): 249-258.

89. Kumar PTS, Srinivasan S, Lakshmanan VH, Tamura H, Nair S, et al. (2011) $\beta$-Chitin hydrogel/nano hydroxyapatite composite scaffolds for tissue engineering applications. Carbohydrate Polymers 85: 584-59.

90. Yang TL (2011). Chitin-based materials in tissue engineering: applications in soft tissue and epithelial organ. International Journal of Molecular Sciences 12(3): 1936-1963.

91. Wan ACA, Tai BCU (2013) Chitin-a promising biomaterial for tissue engineering and stem cell technologies. Biotechnology Advances 31: 1776-1785.

92. Xu C, Lei C, Meng L, Wang C, Song Y, et al. (2012) Chitosan as a barrier membrane material in periodontal tissue regeneration. Journal of Biomedical Materials Research Part B: Applied Biomaterials 100: 14351443.

93. Xu W, Jiang C, Kong X, Liang Y, Rong M, et al. (2012) Chitooligosaccharides and $\mathrm{N}$-acetyl-D-glucosamine stimulate peripheral blood mononuclear cellmediated antitumor immune responses. Molecular Medicine Reports 6: 385-390.

94. Diban N, Stamatialis D (2014) Polymeric hollow fiber membranes for bioartificial organs and tissue engineering applications. Journal of Chemical Technololgy and Biotechnology 89(5): 633-643.

95. Dhandayuthapani B, Yoshida Y, Maekawa T, Kumar DS (2011) Polymeric scaffolds in tissue engineering application: a review. International Journal of Polymer Science, pp. 1-19.

96. Patel H, Bonde M, Srinivasan G (2011) Biodegradable polymer scaffold for tissue engineering. Trends Biomaterials and Artificial Organs 25: 2029.

97. Sudha PN, Aisverya S, Rose MH, Jayachandran V, Kim S-K, et al. (2013) Bionanocomposites of chitosan for multitissue engineering applications. In S-K Kim (Edn), Chitin and chitosan derivatives: Advances in drug discovery and developments. Boca Raton, Florida: CRC Press, Taylor \& Francis Group, pp. 453-460.

98. Jayakumar R, Menon D, Manzoor K, Nair SV, Tamura H (2010) Biomedical applications of chitin and chitosanbased nanomaterials-A short review. Carbohydrate Polymers 82(2): 227-232.

99. Khor E, Lim LY (2003) Implantable applications of chitin and chitosan. Biomaterials 24(13): 2339-2349.

100. Azuma K, Izumi R, Osaki T, Ifuku S, Morimoto M, et al. (2015) Chitin, chitosan, and its derivatives for wound healing: old and new materials. J Funct Biomater 6: 104-142.

101. Thomas D, Thomas S (2013) Chemical modification of chitosan and its biomedical application. In A. Dufresne, S Thomas \& LA Pothan (Eds), Biopolymer nanocomposites processing, properties, and applications. Hoboken: New Jersey: John Wiley \& sons, pp. 33-51.

102. Wysokowski M, Petrenko I, Stelling AL, Stawski D, Jesionowski T, et al. (2015) Poriferan chitin as a versatile template for extreme biomimetics. Polymers 7: 235-265.

103. Synytsya A, Novák M (2013) Structural diversity of fungal glucans. Carbohydr Polym 92: 792-809.

104. Usui S, Tomono Y, Sakai M, Kiho T, Ukai S, et al. (1995) Preparation and antitumor activities of beta- $(1 \rightarrow 6)$ branched $(1 \rightarrow 3)$-beta-D-glucan derivatives. Biol Pharm Bull 18: 1630-1636.

105. Bohn JA, BeMiller JN (1995) (1 $\rightarrow 3$ )- $\beta$-D-glucans as biological response modifiers: A review of structure-functional activity relationships. Carbohydrate Polymers 28(1): 3-14.

106. Brown GD, \& Gordon S (2003) Fungal $\beta$-glucans and mammalian immunity. Immunity 19(3): 311-315.

107. Kogan G, Sandula J, Korolenko TA, Falameeva OV, Poteryaeva ON, et al. (2002) Increased efficiency of Lewis lung carcinoma chemotherapy with a macrophage stimulator-yeast carboxymethyl glucan. Int Immunopharmacol 2(6): 775-781.

108. Kojima T, Tabata K, Itoh W, Yanaki T (1986) Molecular weight dependence of the antitumor activity of schizophyllan. Agric. Biol Chem 50(1): 231-232.

109. Robbins EA, Seeley RD (1977) Cholesterol lowering effect of dietary yeast and yeast fractions. J Food Sci 42: 694-698.

110. Sutherland IW (1998) Novel and established applications of microbial polysaccharides. Trends in Biotechnology 16: 41-46.

111. Yan JK, Wan WQ Wu JY (2014) Recent advances in Cordyceps sinensis polysaccharides: mycelial fermentation, isolation, structure, and bioactivities: a review. Journal of Functional Foods 6: 33-47.

112. Thammakiti S, Suphantharika M, Phaesuwan T, Verduyn C (2004) Preparation of spent brewer's yeast $\beta$-glucans for potential applications in the food industry. Internal Journal of Food Science and Technology 39: 21-29.

113. Mohanty J, Sahoo PK, Pillai BR, Mohanty S, Garnayak SK, et al. (2015) Purification and characterization of $\alpha \beta$-glucan binding protein from the haemolymph of freshwater prawn Macrobrachium rosenbergii. Aquaculture Research 46(1): 95-104.

114. Redmond MJ, Fielder DA (2006) Extraction and purification method for cereal beta-glucan. US patent $012149 \mathrm{~A} 1$.

115. Yoshida T, Honda Y, Tsujimoto T, Uyama H, Azuma J, et al. (2014) Selective isolation of $\beta$-glucan from corn pericarp hemicelluloses by affinity chromatography on cellulose column. Carbohydrate Polymers 111: 538-542.

116. Kitamura S, Hori T, Kurita K, Takeo K, Hara C, et al. (1994) An antitumor, branched (1---3)-beta-D-glucan from a water extract of fruiting bodies of Cryptoporus volvatus. Carbohydr Res 263(1): 111-121.

117. Sawai M, Adachi Y, Kanai M, Matsui S, Yadomae T, et al. (2002) Extraction of conformationally stable (1-6)-branched (1-3)- $\beta$-Dglucans from premixed edible mushroom powders by cold alkaline solution. Int J Med Mushr 4: 197-205. 
118. Ohno N, Kurachi K, Yadomae T (1987) Antitumor activity of a highly branched (1-3)-beta-D-glucan, SSG, obtained from Sclerotinia sclerotiorum IFO 9395. J Pharmacobiodyn 10(9): 478-486.

119. FujimotoS, Furue H, Kimura T, Kondo T, Orita K, et al. (1991) Clinical outcome of postoperative adjuvant immunochemotherapy with sizofiran for patients with resectable gastric cancer: a randomised controlled study. Eur J Cancer 27(9): 1114-1118.

120. Ishibashi K, Miura NN, Adachi Y, Ohno N, Yadoma T (2001) Relationship between solubility of grifolan, a fungal 1,3-beta-D-glucan and production of tumor necrosis factor by macrophages in vitro. Biosci Biotechnol Biochem 65(9): 1993-2000.

121. Blecher P, Mackin W (1995) Betafectin PGG-glucan: a novel carbohydrate immunodulator with anti-infective properties. J Biotechnol Healthcare 2: 207-222.

122. Chihara G, Maeda Y, Hamuro J, Sasaki T, Fukuoka F (1969) Inhibition of mouse sarcoma 180 by polysaccharides from Lentinus edodes. Nature 222(5194): 687-696.

123. Ohno N, Uchiyama M, Tsuzuki A, Tokunaka K, Miura NN, et al. (1999) Solubilization of yeast cell-wall $\beta$-(1-3)-D-glucans by sodium hypochlorite oxidation and dimethyl sulfoxide extraction. Carbohydr Res 316(1-4): 161-172.

124. Chan GC, Chan WK, Sze DM (2009) The effects of beta-glucan on human immune and cancer cells. J Hematol Oncol 2: 25.

125. Majtan J (2013) Pleuran ( $\beta$-Glucan from Pleurotus ostreatus): an effective nutritional supplement against upper respiratory tract infections. Med Sport Sci 59: 57-61.

126. Volman JJ, Helsper JP, Wei S, Baars JJ, van Griensven LJ, et al. (2010) Effects of mushroom-derived beta-glucan-rich -Polysaccharide extracts on nitric oxide production by bone marrow- derived macrophages and nuclear factor-kappaB transactivation in Caco-2 reporter cells: can effects be explained by structure. Mol Nutr Food Res 54: 268-276.

127. Zhang P, Zhang L, Cheng S (1999) Chemical structure and molecular weights of $\alpha$-(1,3)-D-glucan from Lentinus edodes. Biosci Biotechnol Biochem 63: 1197-1202.

128. Sasaki T, Takasuka N (2003) Further study of the structure of lentinan, an antitumor polysaccharide from Lentinus edodes. Carbohydr Res 47(1): 99-104.

129. Zhang M, Cui SW, Cheung PCK, Wang Q (2007) Antitumor polysaccharides from mushrooms: a review on their isolation process, structural characteristics and antitumor activity. Trends Food Sci Technol 18: 4-19.

130. Zimmerman JW, Lindermuth J, Fish PA, Palace GP, Stevenson TT, et al. (1998) A novel carbohydrate-glycosphingolipid interaction between a beta-(1----3)-glucan immunomodulator, PGG-glucan and lactosylceramide of human leukocytes. J Biol Chem 273: 22014-22020.

131. Temelli $F$ (1997) Extraction and functional properties of barley $\beta$-glucan as affected by temperature and $\mathrm{pH}$. Journal of Food Science 62: 1192-1201.

132. Ahmad J (2014) Effect of particle size and temperature on rheology and creep behavior of barley $\beta$-D-glucan concentrate dough. Carbohydrate Polymers 111: 89-100.

133. Brummer Y, Defelice C, Wu Y, Kwong M, Wood PJ, et al. (2014) Textural and rheological properties of oat beta-glucan gels with varying molecular weight composition. J Agric Food Chem 62(14): 3160-3167.

134. Liu YJ (2010) Beta-glucan effects on pasting properties and potential health benefits of flours from different oat lines. Iowa State University. Graduate Theses and Dissertations. Paper 11303.

135. Wood PJ, Braaten JT, Scott FW, Riedel KD, Wolynetz MS, et al. (1994). Effect of dose and modification of viscous properties of oat gum on plasma glucose and insulin following an oral glucose load. British Journal of Nutrition 72: 731-743.

136. Skendi A, Biliaderis CG, Lazaridou A, Izydorczyk MS (2003) Structure and rheological properties of water soluble $\beta$-glucans from oat cultivars of Avena sativa and Avena byzantina. Journal of Cereal Science 38: 15-31.
137. Irakli M, Biliaderis CG, Izydorczyk MS, Papadoyannis IN (2004) Isolation, structural features and rheological properties of waterextractable $\beta$-glucans from different Greek barley cultivars. Journal of the Science of Food and Agriculture 84(10): 1170-1178.

138. Ahmad A, Anjum FM, Zahoor T, Nawaz H, Din A (2009) Physicochemical and functional properties of barley $\beta$-glucan as affected by different extraction procedures. International Journal of Food Science and Technology 44: 181-187.

139. Yao N, Jannink JL, White PJ (2007) Molecular weight distribution of $(1 / 3)(1 / 4)-\beta$-glucan affects pasting properties of flour from oat lines with high and typical amounts of b-glucan. Cereal Chemistry 84: 471479.

140. Lazaridou A, Biliaderis CG, Izydorczyk MS (2003) Molecular size effects on rheological properties of oat $\beta$-glucans in solution and gels. Food Hydrocolloids 17(5): 693-712.

141. Leung MYK, Liu C, Koon JCM, Fung KP (2006) Polysaccharide biological response modifiers. Immunology Letters 105(2): 101-114.

142. Soltanian S, Stuyven E, Cox E, Sorgeloos P, Bossier P, et al. (2009) Betaglucans as immunostimulant in vertebrates and invertebrates. Critical Reviews in Microbiology 35: 109-138.

143. Samuelsen AB, Schrezenmeir J, Knutsen SH (2014) Effects of orally administered yeast-derived beta-glucans: a review. Molecular Nutrition \& Food Research 58(1): 183-193.

144. Du B, Xu BJ (2014) Oxygen radical absorbance capacity (ORAC) and ferric reducing antioxidant power (FRAP) of $\beta$-glucans from different sources with various molecular weight. Bioactive Carbohydrate and Dietary Fibre 3(1): 11-16.

145. Cahill AP, Fenske DJ, Freeland M, Hartwig GW (2003) Beta-glucan process, additive and food product.

146. Sarteshnizia RA, Hosseinia H, Bondarianzadeha D, Colmenerob FJ, Khaksara R, et al. (2015) Optimization of prebiotic sausage formulation: effect of using $\beta$-glucan and resistant starch by D-optimal mixture design approach. LWT e Food Science and Technology 62: 704-710.

147. Kittisuban P, Ritthiruangdej P, Suphantharika M (2014) Optimization of hydroxy propylmethylcellulose, yeast b-glucan, and whey protein levels based on physical properties of gluten-free rice bread using response surface methodology.LWT e Food Science and Technology 57(2): 738-748.

148. Sharafbafi H, Tosh SM, Alexander M, Corredig M (2014) Phase behaviour, rheological properties, and microstructure of oat $\beta$-glucanmilk mixtures. Food Hydrocolloids 41: 274-280.

149. Rinaldi L, Rioux LE, Britten M, Turgeon SL (2015) In vitro bioaccessibility of peptides and amino acids from yogurt made with starch, pectin, or $\beta$-glucan. International Dairy Journal 46: 39-45.

150. Brennan MA, Derbyshire E, Tiwari BK, Brennan CS (2013) Integration of bglucan fibre rich fractions from barley and mushrooms to form healthy extruded snacks. Plant Foods for Human Nutr 68: 78-82.

151. Kim HL, Lee JH, Lee MH, Kwon BJ, Park J (2012) Evaluation of electrospun (1-3) -(1--6)- $\beta$-D-glucans/biodegradable polymer as artificial skin for fullthickness wound healing. Tissue Engineering Part A 18(21-22): 2315-2322.

152. Tungland BC, Meyer D (2002) Non-digestible oligo-and polysaccharides (dietary fiber): their physiology and role in human health and food. Comprehensive Reviews in Food Science and Food Safety 1(90)-109.

153. Venkatachalam G, Narayanan S, Doble M (2013) Applications of cyclic $\beta$-glucans, in name (1st), cyclic $\beta$-glucans from microorganisms: Production, properties and applications. Springer International Publishing.

154. Kofuji K, Huang Y, Tsubaki K, Kokido F, Nishikawa K, et al. (2010) Preparation and evaluation of a novel wound dressing sheet comprised of $\beta$ glucanechitosan complex. Reactive and Functional Polymers 70: 784-789.

155. Delatte SJ, Evans J, Hebra A, Adamson W, Othersen HB, Tagge EP (2001) Effectiveness of beta-glucan collagen for treatment of partial-thickness burns in children. Journal of Pediatric Surgery 36(1): 113-118. 
156. Toklu HZ, Sener G, Jahovic N, Uslu B, Arbak S, et al. (2006) Betaglucan protects against burn-induced oxidative organ damage in rats. International Immunopharmacology 6: 156-169.

157. Sakurai K, Mizu M, Shinkai S (2001) Polysaccharide-polynucleotide complexes.2. Complementary polynucleotide mimic behavior of the natural polysaccharide schizophyllan in the macromolecular complex with single-stranded RNA and DNA. Biomacromolecules 2: 641-650.

158. Belcarz A, Ginalska G, Pycka T, Zima A, Sl osarczyk A, Polkowska I (2013) Application of $\beta$-1,3-glucan in production of ceramics-based elastic composite for bone repair. Central European Journal of Biology 8: $534-548$

159. Kogan G, Stasko A, Bauerova K, Polovka M, Soltes L, et al. (2005) Antioxidant properties of yeast (1---3)- $\beta$-D-glucan studied by electron paramagnetic resonance spectroscopy and its activity in the adjuvant arthritis. Carbohydrate Polymers 61(1): 18-28.

160. Levitz S (2014) $\beta$-Glucan particles as a vaccine platform with intrinsic adjuvanticity (469.3). FASEB Journal 28(1): 469-473.

161. Pillai R, Redmond M, R€oding J (2005) Anti-wrinkle therapy: significant new findings in the non-invasive cosmetic treatment of skin wrinkles with betaglucan. International Journal of Cosmetic Science 27(5): 292.

162. Baschong W, Monglat S, Ochs D (2009) Glucan compositions.

163. Chen SN (2014) Composite glucan and method for preparing the same.

164. Park KM, Park BH, So S, Kim MS, Kim JS, et al. (2001) Composition for external application containing a beta-1,6-branched-beta-1,3- glucan. US patent $0029253 \mathrm{~A} 1$.

165. Ketkeaw R, Oungbho K, Wititsuwannakul R (2012) The $\beta$-glucan from Hevea brasiliensis latex and its possible application in antiaging cosmeceuticals. In 38th Congress on science and technology of Thailand.

166. Vacharaprechakul V, Krisdaphong P, Kanlayavattanakul M (2007) The development and clinical evaluation of carboxymethyl glucan. M.Sc. (Cosmetic Science) Independence Study.

167. Kanlayavattanakul M, Lourith N (2008) Carboxymethylglucan in cosmetics. Thai Pharmaceutical and Health Science Journal 3: 378382.

168. Medeiros SDV, Cordeiro SL, Cavalcanti JE, Melchuna KM, Lima AM, et al. (2013) Effects of purified Saccharomyces cerevisiae (1---3) $\beta$-glucan on Vevnous ulcer healing. International Journal of Molecular Sciences 13(7): 8142-8158.

169. Suzuki T, Nakamura S, Nakayama S, Nishikawa K (2005) Beta-1,3-1,6Dglucan and its use. US patent 0271613 A1. Polymers 92: 792-809.

170. Mitra S (2008) Personal care compositions comprising alpha-glucans and/or beta glucans. US patent $0095731 \mathrm{~A} 1$.
171. Lam KL, Cheung CK (2014) Non-digestible long chain beta-glucans as novel prebiotics. Bioactive Carbohydrate and Dietary Fibre 2(1): 4564.

172. Anusuya S, Sathiyabama M (2014) Preparation of $\beta$-D-glucan nanoparticles and its antifungal activity. International Journal of Biological Macromolecules 70: 440-443.

173. Camelini CM, Maraskin M, De Mendonca MM, Zucco C, Ferreira AG, et al. (2005) Structural characterization of beta-glucans of Agaricus brasiliensis in different stages of fruiting body maturity and their use in nutraceutical products. Biotechnol Lett 27(17): 1295-1299.

174. Jung HK, Hong JH, Park SC, Park BK, Nam DH, et al. (2007) Production and physicochemical characterization of $\beta$-glucan produced by Paenibacillus polymyxa JB115. Biotechnology and Bioprocess Engineering 12(6): 713-719.

175. Siwicki AK, Kazu n K, Glbski E, Terech-Majewska E, Baranowski P, et al. (2004) The effect of beta-1.3/1.6-glucan in diets on the effectiveness of anti-yersinia ruckeri vaccine-an experimental study in rainbow trout (Oncorhynchus mykiss). Polish Journal of Food and Nutrition Sciences 13: 59-61.

176. Volman JJ, Mensink RP, van Griensven LJLD, Plat J, et al. (2010) Effects of $\alpha$-glucans from Agaricus bisporus on ex vivo cytokine production by LPS and PHA-stimulated PBMCs; a placebocontrolled study in slightly hypercholesterolemic subjects European Journal of Clinical Nutrition 64: 720-726.

177. Barsanti L, Passarelli V, Evangelista V, Frassanito AM, Gualtieri P (2011) Chemistry, physico-chemistry and applications linked to biological activities of $\beta$-glucans. Nat Prod Rep 28: 457-466.

178. Du B, Zhu FM, Xu BJ (2014) Physicochemical and antioxidant properties of dietary fibers from Qingke (hull-less barley) flour as affected by ultrafine grinding. Bioactive Carbohydrate and Dietary Fibre 4(2): 170-175.

179. Kim SK, Mendis E, Shahidi F (2007) Marine fisheries by-products as potential nutraceuticals: an overview. In C Barrow \& F Shahidi (Eds), Marine nutraceuticals and functional foods, pp. 2-19 Boca Raton, Florida: CRC Press.

180. Mazumder MA J, Zahir MH, Zaman SF (2014) Advanced materials for gene delivery. Advanced Materials Research 995: 29-47.

181. Nagahama HN, New R, Jayakumar S, Koiwa T, Furuike H Tamura (2008) Carbohydr Polym 73(2): 295-302.

182. Wassila A, Leila A, Lydia A, Abdeltif A (2013) Chitin extraction from crustacean shells using biological methods - A review., Food Technol. Biotechnol 51(1): 12-25. 